\title{
LOS DOCUMENTOS MEDIEVALES COMO FUENTES PARA EL ESTUDIO DE LAS PARROQUIAS E IGLESIAS GALLEGAS: EL DISTRITO DE MONTE DE MEDA (LUGO) ${ }^{1}$
}

\author{
Por \\ JAMES D'EMILIO \\ A Don Amador López Valcárcel \\ en su 70 cumpleaños
}

\section{INTRODUCCIÓN}

En el siglo XII, la mayoría de las iglesias parroquiales de Galicia ya eran antiguas y, en muchos casos, la configuración de sus territorios recordaba la organización de asentamientos de un tiempo todavía más

\footnotetext{
' Esta investigación ha sido financiada en parte por el Research Council y College of Arts and Sciences de la University of South Florida, la Howard Foundation y el National Endowment for the Humanities. Agradezco muy especialmente a Ana Varela Lago por su ayuda en la redacción de este artículo. Agradezco también la colaboración del Archivo Histórico Nacional y del Archivo de la Catedral de Lugo, cuyo director, Don Amador López Valcárcel, ha facilitado mis estudios durante muchos años de investigación en Lugo. A él le dedico este artículo en homenaje a su dedicación a su labor y en agradecimiento a su generosidad y constante buen humor.

En los topónimos, uso la letra itálica para las formas antiguas e incluyo el nombre actual entre paréntesis. En los nombres personales, elijo una forma usada en la citada documentación y uso la letra itálica para señalar variantes ortográficas cuando éstas puedan ser relevantes. Empleo el título Don o Doña únicamente cuando aparece en el texto citado. Cito los pergaminos de la sección del Clero del Archivo Histórico Nacional (AHN Clero) por número de carpeta y de documento.
}

"CUADERNOS DE ESTUDIOS GALLEGOS", Tomo XLIII, Fascículo 108, Santiago 1996. 
lejano. Sin embargo, hay pocos documentos de la Galicia altomedieval, en comparación con los de los siglos XII y XIII, y los más fiables tratan de los pequeños distritos que rodearon los monasterios principales y sus dominios. Los privilegios que citan gran número de iglesias son precisamente los que han sufrido más falsificaciones e interpolaciones. Solo a partir de los siglos XII y XIII encontramos documentación abundante y fiable sobre las parroquias de amplias zonas de Galicia.

Si bien es cierto que la red parroquial ya se había aproximado a su estructura moderna a finales del siglo XII, los documentos de los siglos XII y XIII guardan las huellas de los orígenes y la trayectoria histórica de muchas iglesias. En combinación con la toponímia, la geografía y la arqueología, estos documentos nos ayudan a recuperar la historia de la formación de la red parroquial. Las marcadas diferencias en la extensión de las parroquias, los cambios de sus advocaciones, la terminología especial reservada para ciertas iglesias, sus diversos propietarios - representando toda la gama de la sociedad medieval — todos son vestigios del largo y complejo proceso histórico que forjó la red parroquial de los siglos XII y XIII que ha perdurado en buena parte hasta nuestros días. El estudio de estas fuentes también ofrece un contexto para el análisis crítico de la más controvertida documentación altomedieval, facilitando así la recuperación de su valor histórico.

Un amplio análisis interpretativo del desarrollo de la red parroquial exige cuidadosos estudios preliminares de pequeños distritos. En estos estudios es posible reunir toda la documentación existente anterior al último cuarto del siglo XIII. Esta documentación nos permitirá tratar cuestiones como las relaciones entre las villas y las parroquias, el papel de las familias nobles y las grandes instituciones eclesiásticas en la configuración de las parroquias, las relaciones entre las parroquias y otras formas de organización territorial, las diversas modalidades de repartición de iglesias propias entre varios propietarios, y el papel del clero parroquial. Al mismo tiempo, el manejo de la documentación de una zona reducida nos alerta a las prácticas de los notarios y escribas, permitiendo un análisis más preciso de su terminología. La evidencia acumulada a través de estos estudios locales nos ayudará a plantear las preguntas a tratar en un estudio más amplio sobre la formación de la red parroquial.

Los estudios locales también pueden complementar las tendencias imperantes en la actual historiografía medieval de Galicia, comprometida 
con los métodos cuantatitivos y la consideración de los estamentos sociales - clero, nobleza, campesinado, burguesía - como los verdaderos sujetos de una historia centrada en las formas de explotación de la tierra y el reparto de sus frutos. ${ }^{2} \mathrm{Si}$ tales preocupaciones surgieron de la confluencia de la tradición marxista con los estudios regionales de la historiografía francesa, también es cierto que la misma naturaleza de las fuentes documentales de Galicia y el pésimo estado de su publicación han orientado la historiografía actual al estudio de los dominios de las mismas instituciones eclesiásticas cuyos archivos se han conservado, desaconsejando la investigación de problemas que exijan un rastreo - no meramente cuantitativo- de documentos de distintas instituciones en búsqueda de datos no fácilmente reducibles a cifras. ${ }^{3}$

Este artículo se centra en las parroquias del distrito de Monte de Meda, situado en los municipios actuales de Guntín y Lugo. En los siglos XII y XIII, estas parroquias fueron integradas en los cotos de la catedral de Lugo

${ }^{2}$ Sobre la historiografía medieval en Galicia: E. Portela Silva y M. C. Pallares Méndez, «Historiografía sobre la Edad Media de Galicia en los diez últimos años (19761986),» Studia Histórica VI (1988), 7-25. E. Portela Silva y M. C. Pallares Méndez, «La investigación histórica sobre Galicia en la Edad Media,» Galicia e a Historiografía, Semata V (1993), 73-106. Además de los estudios monográficos citados en la nota siguiente, unos trabajos representativos de las líneas dominantes en la actual historiografía medieval en Galicia son: E. Portela Silva, La región del Obispado de Tuy en los siglos XII a XV, Santiago 1976; E. Portela Silva, La colonización cisterciense en Galicia (1142-1250), Santiago 1981; R. Pastor et al., Poder monástico y grupos domésticos en la Galicia Foral (siglos XIII-XV): la casa, la comunidad, Madrid 1990; M. L. Ríos Rodríguez, As orixes do foro na Galicia Medieval, Santiago 1993.

${ }^{3}$ Entre el creciente número de estudios de los dominios de las instituciones eclesiásticas en Galicia se puede citar: M. C. Pallares Méndez, El Monasterio de Sobrado: un ejemplo del protagonismo monástico en la Galicia medieval, La Coruña 1979; D. Mariño Veiras, Señorío de Santa María de Meira (de 1150 a 1525). Espacio rural, régimen de propiedad y régimen de explotación en la Galicia medieval, La Coruña 1983; J. Barreiro Somoza, El Señorío de la iglesia de Santiago de Compostela (Siglos IXXIII), La Coruña 1987; F. J. Pérez Rodríguez, El Dominio del Cabildo Catedral de Santiago de Compostela en la Edad Media (Siglos XII-XIV), Santiago 1994.

Sobre las fuentes documentales: S. Jiménez Gómez, Guía para el estudio de la Edad Media Gallega, Santiago 1973; X. R. Barreiro Fernández et al., Inventario das fontes documentais da Galicia Medieval, Santiago 1988; J. I. Fernández de Viana y Vieites, «Las fuentes documentales gallegas de la Edad Media,» Galicia en la Edad Media, Actas del Coloquio de la Sociedad Española de Estudios Medievales...13-17 Julio 1987, Madrid 1990, 1-7.

"CUADERNOS DE ESTUDIOS GALLEGOS", Tomo XLIII, Fascículo 108, Santiago 1996. 
y del monasterio de Ferreira de Pallares. La proximidad a estos centros eclesiásticos nos proporciona una documentación relativamente abundante sobre unas parroquias que también plantean los problemas típicos del estudio de las iglesias gallegas y la red parroquial.

El artículo comienza con una breve introducción al estudio de la formación de la red parroquial; luego considera las referencias a este distrito en la documentación altomedieval, su integración en los cotos de Lugo y Ferreira de Pallares en el siglo XII, y la organización de las merindades del coto de Lugo en el siglo XIII. La más amplia documentación del siglo XIII nos permitirá seguir la carrera del merino Rudericus Petri Bazarius, examinar el desarrollo de las iglesias propias de la zona, y considerar el creciente protagonismo del clero parroquial. El artículo concluye con unas reflexiones sobre la diversidad de iglesias que integran la red parroquial de este distrito.

\section{LA FORMACIÓN DE LA RED PARROQUIAL}

Aunque la trascendencia de la parroquia como marco de vida religiosa y unidad de organización territorial en Galicia es bien conocida, se sabe poco acerca de los orígenes de las parroquias y sus iglesias. ${ }^{4}$ La validación de las sugerentes propuestas de algunos investigadores que buscan los antecedentes de las parroquias en los castros antiguos o las villas romanas se ve frustrada por la oscuridad que envuelve la cristianización de Galicia. ${ }^{5}$ Más importante, el estudio de los orígenes de las iglesias rurales o de los marcos territoriales de las parroquias forma sólo una parte del estudio de la implantación de la red parroquial en Galicia. Este estudio plantea toda una serie de preguntas sobre las relaciones entre las comunidades locales y los centros administrativos de la iglesia gallega, y

${ }^{4}$ Para una visión global: J. Fariña Jamardo, La parroquia rural en Galicia, Madrid 1975, 11-119.

${ }^{5}$ Para un resumen de las distintas opiniones sobre las relaciones entre los castros y las parroquias y la supuesta evolución, castro-villa-parroquia: Fariña Jamardo (1975), 4958. Sobre la cristianización de Galicia: M.C. Diaz y Diaz, «Early Christianity in Lugo,» Classical Folia XXXII (1978), 243-59; A. Tranoy, La Galice Romaine. Recherches sur le nord-ouest de la péninsule ibérique dans l'Antiquité, Paris 1981, 423-34, 443-44.

"CUADERNOS DE ESTUDIOS GALLEGOS", Tomo XLIII, Fascículo 108, Santiago 1996. 
la integración de las diversas iglesias rurales en una red más homogénea de parroquias con reconocidos derechos, funciones y obligaciones dentro de la nueva estructuración de las instituciones eclesiásticas surgida de las reformas y la legislación canónica de los siglos XI, XII y XIII.

El primer texto que ofrece una visión global de la organización eclesiástica - y quizás de una red parroquial — del noroeste peninsular es el llamado Parroquial Suevo del siglo VI que ha sido relacionado con la actividad pastoral de Martín de Braga. ${ }^{6}$ Las grandes circunscripciones marcadas en este documento dejaron su huella posteriormente en algunos de los arcedianatos y arciprestazgos de Galicia y podrían representar los primeros intentos por parte de la jerarquía eclesiástica de centralizar la vida religiosa en las amplias zonas rurales donde iban surgiendo iglesias como resultado de iniciativas locales.

Hay que esperar hasta el siglo X para encontrar un número suficiente de documentos fiables que nos permitan estudiar la organización eclesiástica de la Galicia rural, al menos en unas zonas privilegiadas en torno a los grandes cenobios, como Samos, Sobrado y Celanova, que guardan gran número de documentos de esta época en los cartularios confeccionados en los siglos XII y XIII. ${ }^{7}$ Estos revelan una red de iglesias bien desarrollada, a veces con una densidad superior a la actual red parroquial. En estos textos, las iglesias empiezan a sustituir a las villas como puntos de referencia en la organización de la vida rural. ${ }^{8}$ De los

${ }^{6}$ Una edición del texto forma parte del estudio de P. David, «L'organisation ecclésiastique du royaume suève au temps de Saint Martin de Braga,»Études historiques sur la Galice et le Portugal du VIe au XIIe siècle, Paris 1947, 1-82. Cfr. Fariña Jamardo (1975), 65-76; R. Fletcher, Saint James's Catapult: the Life and Times of Diego Gelmirez of Santiago de Compostela, Oxford 1984, 229-31; F. López Alsina, La ciudad de Santiago de Compostela en la Alta Edad Media, Santiago 1988, 155-63, 309-10; A. Isla Frez, La sociedad gallega en la Alta Edad Media, Madrid 1992, 10-16; C. Baliñas Pérez, Do mito á realidade: a definición social e territorial de Galicia na Alta Idade Media (séculos VIII e IX), Santiago 1992, 137-38; D. Mansilla, Geografía eclesiástica de España. Estudio histórico-geográfico de las diocesis, Roma 1994, I, 189-92, 212-37.

${ }^{7}$ El Tumbo de San Julián de Samos, ed. M. Lucas Alvarez, Santiago 1986; Tumbos del Monasterio de Sobrado de los Monjes, ed. P. Loscertales de G. de Valdeavellano, Madrid 1976, 2 tomos; O Tombo de Celanova, ed. J. M. Andrade Cernadas, Santiago 1995, 2 tomos.

${ }^{8}$ Fariña Jamardo esboza el desarrollo de la compleja relación entre las villas y las iglesias: (1975), 110-19. Cfr. A. Sampaio, Estudos históricos e económicos I: As vilas do norte de Portugal, $2^{\text {a }}$ edición, Lisboa 1979, 59-65, 135-42.

"CUADERNOS DE ESTUDIOS GALLEGOS", Tomo XLIII, Fascículo 108, Santiago 1996. 
diversos orígenes de estas iglesias, bien iglesias propias fundadas por individuos o comunidades, bien monasterios o iglesias que integraron pequeñas congregaciones monásticas, se puede deducir que muchas no disfrutaban de los derechos ni cumplían las funciones que asociamos con la parroquia.

Es difícil determinar si una red tan densa de iglesias se extendió a las zonas más alejadas de los centros religiosos, ya que tales zonas han conservado pocos documentos de la época. Además, la misma circunstancia que nos descubre esta red de iglesias - la presencia de un gran monasterio- debe haber condicionado el desarrollo de la vida religiosa en sus alrededores. La documentación altomedieval de las diócesis de Lugo e Iria nos ofrece una visión de la organización eclesiástica de zonas más amplias, pero su interpretación se ve supeditada a los notorios problemas de interpolación o falsificación que afectan a sus textos más importantes.

A pesar de ello, Fernando López Alsina ha demostrado el valor de esta documentación mediante un análisis penetrante del llamado Documento de Tructino del año 868. Esto le ha permitido esbozar la evolución de la red parroquial iriense en estos siglos oscuros. ${ }^{9}$ Según este autor, las parroquias de esa época - frecuentemente llamadas diócesis en la documentación altomedieval - ocupaban una gran extensión comparable a la de los commissos. Cada parroquia albergaba un número creciente de iglesias rurales. Estas feligresías incluyeron a varias villas, creando así un nuevo marco territorial en la sociedad rural. Con los grandes cambios eclesiásticos, fruto de la nueva relación entre la iglesia hispánica y la romana forjada en la segunda mitad del siglo XI, las feligresías asumieron los derechos y funciones de las parroquias antiguas, y éstas se convirtieron, en algunos casos, en arciprestazgos o arcedianatos.

En el caso de Lugo, las largas listas de posesiones de la mitra en el testamento mayor del obispo Odoario, atribuido al año 747, y el privilegio de Alfonso III del año 897 ofrecen una visión de conjunto de las iglesias

${ }^{9}$ López Alsina (1988), 155-74, 311-13. El documento de Tructino fue publicado por A. López Ferreiro, Historia de la Santa A. M. Iglesia de Santiago de Compostela, Santiago 1898-1911, II, ap. ii, 6-8. Sobre la organización territorial de Galicia en la alta edad media, Isla Frez (1992), 140-51.

"CUADERNOS DE ESTUDIOS GALLEGOS", Tomo XLIII, Fascículo 108, Santiago 1996. 
de la diócesis altomedieval. ${ }^{10}$ Es bien sabido que estos documentos han sido objeto de una crítica feroz que ha descalificado todo el ciclo odoariano y los privilegios lucenses de Alfonso II y Alfonso III como falsificaciones. ${ }^{11}$ No es éste el lugar para la discusión meditada que estos documentos y su fortuna en la crítica documental merecen, aunque no

${ }^{10}$ El testamento mayor de Odoario se conserva únicamente en el Tumbo Viejo del siglo XIII (AHN Códices 1043B, f. 1v-3r); del privilegio alfonsino hay dos versiones, la del Tumbo Viejo (AHN Cód. 1043B, f. 28r-30v) y un pseudo-original (Archivo de la Catedral de Lugo, lib. X, no. 2), atribuido a «fines del siglo XI o comienzos del XII» por M. R. García Alvarez, «Catálogo de documentos reales de la Alta Edad Media referentes a Galicia (714-1109),» Compostellanum VIII (1963), 154.

Ambos documentos fueron editados con comentarios por A. Floriano Cumbreño, Diplomática española del período astur, I, Oviedo 1949, 48-54, II, Oviedo 1951, 226-37. Su edición del privilegio alfonsino se tomó del texto del Tumbo Viejo, pero él notó las variaciones con la versión del Tumbo Nuevo del siglo XVIII (AHN Cód. 267B, f. 8r-12v) copiada del pseudo-original. A. García Conde también editó el testamento de Odoario: «Documentos Odoarianos,» Boletín de la Comisión de Monumentos Históricos y Artísticos de Lugo IV (1950), 84-99.

" Además de los trabajos de Floriano Cumbreño $(1949,1951)$ y García Conde (1950) y las notas breves sobre los documentos reales en los catálogos de García Alvarez (1963) y L. Sánchez Belda (Documentos Reales de la Edad Media referentes a Galicia. Catálogo de los conservados en la Sección de Clero del Archivo Histórico Nacional, Madrid 1953), las discusiones más relevantes de estos documentos son: L. BarrauDihigo, «Etude sur les actes des rois asturiens (718-910),» Revue Hispanique XLVI (1919), 72-90, 119-24, 150-1; L. Barrau-Dihigo, «Recherches sur l'histoire politique du royaume asturien,» Revue Hispanique LII (1921) 79-85. 100-2, 321-7; P. David, «La métropole ecclésiastique de Galice du VIIIe au XIe siécle. Braga et Lugo,» Études historiques... (1947), 133-38, 143-48; L. Vázquez de Parga, «Los documentos sobre las presuras del obispo Odoario,» Hispania X (1950), 635-80; Fariña Jamardo (1975), 84-7; Isla Frez (1992), 49-52, 54-61; M. Lucas Alvarez, «Las cancillerías reales astur-leonesas (718-1072), El Reino de León en la Alta Edad Media VIII, León 1995, 102-6, 120-23. En defensa de la autenticidad de la historia de Odoario, cfr., A. García Conde, «El Obispo Odoario: datos de su vida a la luz de un documento de 954,» Boletín...de Lugo I (1942), 25-29, 57-60; García Conde, «Documentos Odoarianos,» Boletín...de Lugo IV (1950-1), 161-67, 241-48; M. R. García Alvarez, «Odoario y sus inmediatos sucesores en la sede lucense,» Boletín...de Lugo VIII (1967-8), 149-61; C. Sánchez Albornoz, «Documentos de Odoario y sus familiares sobre la restauración de Lugo,» Estudios sobre Galicia en la temprana Edad Media, La Coruña 1981, 21-41; A. García Conde y A. López Valcárcel, Episcopologio Lucense, Lugo 1991, 53-72, 85-94; Baliñas Pérez (1992), 168-71, 53436, 547-51. Las observaciones de López Alsina apuntan a una revalorización de los documentos odoarianos en la línea de sus estudios de los privilegios antiguos de Compostela: (1988), 28-30, 40-43, 103-5; cfr. Fletcher, (1984), 62-64; P. Linehan, History and the Historians of Medieval Spain, Oxford 1993, 100-1.

"CUADERNOS DE ESTUDIOS GALLEGOS", Tomo XLIII, Fascículo 108, Santiago 1996. 
negamos sus graves problemas diplomáticos y evidentes anacronismos. De todas formas, buena parte de la crítica se ha dirigido a los aspectos diplomáticos y a la manipulación de los textos en relación con los pleitos surgidos de la reorganización eclesiástica a finales del siglo XI: la restauración de las sedes de Ourense y Tui y de la metropolitana de Braga, las aspiraciones de Compostela, y las pretensiones expresadas en los documentos pelagianos de Oviedo. ${ }^{12}$ Si la forma en que nos han llegado los documentos lucenses es el resultado, en parte, de su uso interesado en los conflictos jurisdiccionales con las diócesis vecinas, ésto no les quita todo el valor histórico de un contenido que, precisamente por su verosimilitud, podría haber prestado más credibilidad a las reivindicaciones de la sede.

Para apreciar la relevancia de esta documentación lucense al estudio de la red parroquial en la alta edad media, convendría ver con más atención y quizás más simpatía a las amplias relaciones de propiedades e iglesias que Vázquez de Parga, uno de los más acertados críticos de los documentos odoarianos, desdeñó, en una ocasión, como «una monótona lista de villas e iglesias que llenan cinco páginas de laEspaña Sagrada». ${ }^{13}$ Antonio García Conde, con su cuidadosa identificación de los lugares nombrados en el testamento de Odoario, dio el primer paso hacia la recuperación del valor histórico de estas listas de iglesias. ${ }^{14}$ Se necesita un análisis más detenido de las relaciones entre la lista de iglesias y heredades en el testamento de Odoario y la del privilegio de Alfonso III, y una investigación de las relaciones de estas iglesias y heredades con la sede

\footnotetext{
${ }^{12}$ Sobre la reorganización eclesiástica del siglo XI, los conflictos entre las diócesis del noroeste peninsular en el siglo XII, y la manipulación interesada de la historia eclesiástica de la alta edad media: L. Vázquez de Parga, La División de Wamba, Madrid 1943, 43-47; B. Cañizares, «Los grandes pleitos de la Iglesia de Lugo,» Boletín...de Lugo I (1944), 229-32, 296-98; D. Mansilla, «Disputas diocesanas entre Toledo, Braga y Compostela en los siglos XII al XV,» Anthológica Annua III (1955), 89-130; Mansilla, «La supuesta metrópoli de Oviedo,» Hispania Sacra VIII (1955), 259-74; F. J. Fernández Conde, El Libro de los Testamentos de la Catedral de Oviedo, Roma 1971, 56-58, 72-80, 370-72; Fletcher, The Episcopate in the Kingdom of León in the Twelfth Century, Oxford 1978, 190-93, 195-203; L. Vones, Die Historia Compostellana und die Kirchenpolitik des nordwestspanischen Raumes 1070-1130, Colonia 1980, 77-99, 133-473; Fletcher (1984), 192-210.

${ }^{13}$ Vázquez de Parga (1950), 646-7.

${ }^{14}$ García Conde (1950), 84-99.
}

"CUADERNOS DE ESTUDIOS GALLEGOS", Tomo XLIII, Fascículo 108, Santiago 1996. 
lucense usando los más fiables inventarios del siglo XII, y la amplia documentación, tanto privada como episcopal, de los siglos XII y XIII. ${ }^{15}$

En estos siglos, la abundante documentación de la catedral de Lugo y los monasterios lucenses nos proporciona datos sobre las iglesias y parroquias de amplias zonas de la diócesis. Más que el mero incremento de la documentación disponible, el nuevo protagonismo de las parroquias facilita su estudio, confirmando la consolidación de una red parroquial con los territorios bien demarcados, las rentas aseguradas por los diezmos y demás prestaciones, y los clérigos dedicados a la cura de almas, fruto de la recepción de la legislación canónica sobre la parroquia que culminó en los cánones del Cuarto Concilio Laterano. En la vecina diócesis de Braga, el Censual del obispo D. Pedro nos ofrece una relación de 573 feligresías y sus prestaciones a la sede. ${ }^{16}$ Procedente de una diócesis recién instaurada, el Censual es testimonio importante del desarrollo de la organización diocesana y la red parroquial rural ya a finales del siglo XI.

Aunque en Galicia no gozamos de ninguna fuente comparable al Censual de Braga, un análisis paciente de las noticias escuetas dispersas en una gran variedad de fuentes nos permite ver la red parroquial lucense y la diversidad de las iglesias que la integraron. A partir del siglo XII, un creciente número de ventas, donaciones o permutas de tierras mencionan la parroquia donde se hallan las propiedades. Con el avance del siglo XIII, los miembros del clero parroquial son identificados más a menudo entre los testigos de las transacciones, y algunos dejaron sus propios testamentos. A veces, los documentos tratan de las iglesias mismas con sus derechos y prestaciones, mostrándonos la vitalidad del sistema de iglesias propias, la lenta introducción del concepto del ius patronatus, y el

\footnotetext{
${ }^{15}$ Las listas de posesiones más importantes son la división de bienes entre el obispo y el cabildo en 1120 copiada en el Tumbo Viejo (AHN Cód. 1043B, f. 49r-50r) y publicada por M. Risco, España Sagrada, XLI, Madrid 1798, ap. ii, pp. 296-301; una relación de mediados del siglo XII de los bienes perdidos por el cabildo (AHN Clero $1326 \mathrm{C} / 3$ y Cód. 1043B, f. 51rv); un inventario de mediados del siglo XII de las posesiones del cabildo (AHN Cód. 1043B, f. 51v-54r), publicado por García Conde, «Inventario de bienes de la mesa canonical de Lugo,» Boletín...de Lugo IX (1976), $307-$ 20; y una lista, posterior al año 1196, de las posesiones y adquisiciones de la sede en las comarcas de Deza y Dozón (AHN Clero 1326C/2, 4).

${ }^{16} \mathrm{P}$. Avelino de Jesus da Costa, O Bispo D. Pedro e a organizaçâo da diocese de Braga, 2 tomos, Coimbra 1959.
}

"CUADERNOS DE ESTUDIOS GALLEGOS", Tomo XLIII, Fascículo 108, Santiago 1996. 
papel de los propietarios o patronos, tanto laicos como clérigos o instituciones eclesiásticas. Aunque la fundación de la gran mayoría de estas iglesias se remonta a los siglos anteriores, los documentos de los siglos XII y XIII todavía apuntan a sus orígenes diversos y nos iluminan acerca del complicado y a veces conflictivo proceso de su incorporación en una red de parroquias con derechos y funciones similares.

\section{LA ZONA DE MONTE DE MEDA EN LA DOCUMENTACIÓN ALTOMEDIEVAL}

La zona en torno a Monte de Meda es cruzada actualmente por la carretera nacional que une Lugo con Santiago y Ourense. ${ }^{17}$ A ambos lados de la carretera, las tres pequeñas parroquias de Monte de Meda - Sta. Madanela, San Martiño y San Cibrao- ocupan los altos que separan los municipios de Lugo y Guntín. Bajando hacia Lugo, se encuentran las parroquias de Sta. Eulalia de Lamas, San Pedro de Calde y, al este, San Remixio de Bazar. Al este y sur de Monte de Meda, donde comienzan los regatos que bajan al río Ferreira, se hallan las parroquias más extensas de San Miguel de Constante, San Salvador de Castelo y Sta. Eulalia de Pradeda. Al oeste de Monte de Meda, están ubicadas las parroquias de Santiago de Gomelle y Sta. Mariña de Lamela, y, más lejos, la de Sta. María de Sirvián. Siguiendo los regatos que bajan hacia el río Ferreira, se entra en las parroquias de Santiago de Entrambasaugas y San Martiño de Vilameá.

El único lugar de este distrito incluido en el testamento mayor de Odoario es villa Lamela que, como señaló García Conde, corresponde al lugar de la parroquia de Sta. Mariña de Lamela. ${ }^{18}$ El hecho de que Villa

${ }_{17}$ Sobre la antigua red viaria de este distrito: E. Ferreira Priegue, Los Caminos Medievales de Galicia, Boletín Auriense, Anexo IX, Ourense 1988, 234, 242-44.

${ }^{18}$ García Conde (1950), 91. N. Rielo Carballo identificó Villamediana con San Martiño de Vilameá: E. Valiña Sampedro et al., Inventario artístico de Lugo y su provincia, VI, Madrid 1983, 298-99. De hecho, ese lugar es localizado in ripa sarriae y relacionado con Villa de Atraissi (Estraxiz), así que corresponde a un lugar de la parroquia actual de San Martiño de Romelle (Samos). Estas formaron parte de un pleito entre la catedral y la abadía de Samos resuelto en 1195: Tumbo de...Samos (1986), doc. 49, pp. 145-48.

"CUADERNOS DE ESTUDIOS GALLEGOS", Tomo XLIII, Fascículo 108, Santiago 1996. 
Lamela ocupe el segundo lugar en la larga relación de posesiones, fuera de la lógica geográfica que se impone ẹ gran parte de la lista, me hace sospechar que sea una adición posterior a las listas más coherentes que formaron el núcleo del texto.

El privilegio de Alfonso III amplía la información sobre este distrito al confirmar las iglesias de Entrambasaugas, Lamela, Pradeda y San Fiz do Ermo como posesiones de la sede en la comarca de Ferreira:

In terra de Ferraria ecclesiam Sancti Iacobi de Senari qui dicitur Interambasaquas cum uillis et familiis; ecclesiam Sancte Marine de Lamela cum cauto et familia; ecclesiam Sancte Eulalie de Plataneta cum adiunctionibus suis et familia; ecclesiam Sancti Felicis de Heremo cum ecclesiis, uillis et familiis ab auis nostris ibidem concessis. ${ }^{19}$

De San Fiz do Ermo, que perteneció a los Templarios en el siglo XIII, sólo queda el lugar de Sanfiz en la parroquia de Entrambasaugas, pero la documentación altomedieval avala la antigüedad de una fundación monástica con iglesias dependientes. ${ }^{20}$ En el caso de la iglesia de Entrambasaugas, la designaciónSancti Iacobi de Senari se refiere al lugar de Sear en la actual parroquia, pero el nombre de Interambasaquas ya había

${ }^{19}$ Archivo de la Catedral de Lugo, lib. X, no. 2.

${ }^{20} \mathrm{~F}$. Vázquez Saco, «Iglesias románicas de la provincia de Lugo: iglesia parroquial de Santiago de Entrambasaguas,» Boletín...de Lugo I (1943), 120-22. El monasterio, junto con el de Sta. María de Carteire, recibió una donación del conde Osorio Vistruariz y ganó un pleito en el siglo X: AHN Clero 1325A/6, 8. Ambos traslados fueron hechos por Vimara presbiter hacía finales del siglo XI, y B. Cañizares argumentó con razón que el copista cambió las fechas, que debieran ser de 922 (1325A/8) y 956 (1325A/6): Colección diplomática de la catedral de Lugo, ms. del Archivo de la Catedral de Lugo, t. I, nos. 27 y 39. El abad Iohannes de Sancto Felix de Heremo fue citado en AHN Clero 1325D/16 (24.II.1158), y el coto de San Fiz fue mencionado repetidamente en la segunda mitad del siglo XII: 1082/12 (29.IV.1166), 14 (10.VI.1168) y 16 (10.II.1187).

Para los templarios, una serie de documentos narra sus pleitos con el monasterio vecino de Ferreira de Pallares, AHN Clero 1083/18, 19 (6.IV.1227), 1084/3 (15.I.1229), 1085/9 (18.VIII.1241), 1091/1 (14.I.1268), 1096/20, y 1097/10. San Fiz do Ermo fue citado con las iglesias dependientes de Carteire y Marzán entre las posesiones de los Templarios en un acuerdo con el obispo de Lugo, AHN Clero 1328B/24 (12.IX.1244), publicado con muchos errores en España Sagrada, XLI, ap. xxxvi, pp. 371-73 con fecha errónea de 1254.

"CUADERNOS DE ESTUDIOS GALLEGOS", Tomo XLIII, Fascículo 108, Santiago 1996. 
sustituido al de Senari antes de 1100. Esto sugiere que el nombre antiguo puede proceder de los documentos más antiguos que constituyeron el fondo histórico de la versión del privilegio preparado hacia 1100.

La gran extensión de las parroquias de Lamela, Pradeda y Entrambasaugas en relación a las otras de la zona también puede corroborar la antigüedad de estas circunscripciones. ${ }^{21}$ Con una superficie de 1.475 hectáreas, la parroquia de Entrambasaugas hoy supera con creces la extensión de las circundantes, y sólo una pequeña parte de esta extensión se debe a la anexión de San Fiz do Ermo. ${ }^{22}$ Por su parte, las parroquias de Lamela y Pradeda gozan de superficies cercanas a las 700 hectáreas, y la diferencia que las separa de las parroquias vecinas aumenta si consideramos que la parroquia actual de Vilameá (515 hectáreas) incluye las antiguas de Trastulfe y Pradedo, mientras la de Sirvián (610 hectáreas) incluye la antigua parroquia de Montouto.

Es evidente que la extensión de una parroquia es el resultado de múltiples factores históricos y geográficos que no derivan simplemente de la fecha o las circunstancias de su fundación, pero tan marcadas diferencias entre las parroquias de una misma zona ponen de manifiesto sus distintas trayectorias históricas. En este caso, cabe preguntarse si una antigua posesión episcopal de las tres iglesias, afirmada por el privilegio de Alfonso III, con la consiguiente delimitación de sus territorios explicaría una extensión que habría resistido la fragmentación del distrito colindante en parroquias más pequeñas, quizás fundadas como iglesias propias en territorios más reducidos. Con estos argumentos no pretendo defender la autenticidad del privilegio atribuido a Alfonso III, pero sí señalar su utilidad como fuente para la historia de las parroquias lucenses.

${ }^{21}$ La superficie de estas parroquias está tomada de R. Miralbes Bedera, M. P. de Torres Luna y R. Rodríguez Martínez-Conde, Mapa de límites de las parroquias de Galicia, Santiago de Compostela 1979, 41-2. El número elevado de lugares poblados también distingue las parroquias de Pradeda, con once, y Entrambasaugas -con doce sin contar el lugar de Sanfiz.

${ }^{22}$ Varios lugares de la actual parroquia fueron asignados a ella ya en los siglos XII y XIII: Penela, AHN Clero 1082/16 (10.II.1187); Xoaine, 1197/1 (1196); Río, Sear y Xoaine, 1327H/6 (I.1242).

"CUADERNOS DE ESTUDIOS GALLEGOS", Tomo XLIII, Fascículo 108, Santiago 1996. 


\section{LA DEMARCACIÓN DE LOS COTOS DE LUGO Y FERREIRA DE PALLARES}

En el año 1027, Alfonso V confirmó la donación de las tres cuartas partes del condado de Mera concedida a la sede por Bermudo II. En la versión copiada en el Tumbo Viejo se añadió una supuesta confirmación de los términos del coto de Lugo con sus descripciones. García Conde y Vázquez Saco fecharon esta interpolación entre la restauración de la sede de Braga en 1070 y el acuerdo de 1078 sobre la demarcación del coto de Lugo, relacionándola con los conflictos que sucedieron a la muerte de Fernando I. ${ }^{23}$ La descripción fue utilizada en el reconocimiento del año 1078 e incorporada en el texto de la resolución del pleito entre el obispo D. Vistruario y los condes que habían invadido el coto y usurpado sus derechos. Para la zona que nos interesa, la versión interpolada del privilegio de 1027 traza los términos así:

...per illa lagena de Fargaloxi et per uereda qui discurrit inter Sancto Uereisimo et Constanti, et inde super Sancta Maria de Transmonte, et inde ad Montem de Meta, et inde ad portella de Linares, et inde per illo cerro de Monte Auto, et inde inter Bretenos et Sancto Petro de Mera, et inde inter Borrekes et Sancta Maria... ${ }^{24}$

La pervivencia de la mayoría de los topónimos nos permite afirmar que, en el siglo XI, los límites del coto se aproximaron a los de las parroquias actuales de Bazar, Sta. Madanela de Monte de Meda, Lamas, Poutomillos, Bacurín, Mera, San Román de Retorta y Sta. Cruz de Retorta, todas situadas dentro del coto. ${ }^{25}$ De éstas, el texto alude a tres: San Pedro de Mera, Sta. Madanela de Monte de Meda con la antigua designación de Sancta Maria de Transmonte, y San Remixio de Bazar con

${ }^{23}$ Archivo de la Catedral de Lugo, lib. X, no. 7; AHN Cód. 1043B, f. 8v-9v. El original fue publicado en García Conde y Vázquez Saco, «Diploma de Don Alfonso V,» Boletín...de Lugo I (1943), 162-68; cfr. García Conde y Vázquez Saco, «Un diploma de Bermudo II,» Boletín...de Lugo I (1942), 91-99. El texto del acuerdo del año 1078 (AHN Cód. 1043B, f. 37r-38v) fue publicado en España Sagrada, XL, ap. xxviii, pp. 417-22.

${ }^{24}$ AHN Cód. 1043B, f. 9r.

${ }^{25}$ Fargaloxi es Fargós en la parroquia de Constante. Bretenos y Borrekes son Bretios y Borreiques en las parroquias de Sirvián y Sta. Cruz de Retorta respectivamente

"CUADERNOS DE ESTUDIOS GALLEGOS", Tomo XLIII, Fascículo 108, Santiago 1996. 
su antiguo titular, Sancto Uereisimo. ${ }^{26}$ Fuera del coto, Sancta Maria se corresponde con la iglesia actual de Sta. María de Sirvián.

El pleito del año 1078 deja patente el peso de la nobleza gallega en este distrito. Entre las familias nobles de la zona destaca un linaje cuyos miembros fueron benefactores del monasterio de Ferreira de Pallares y la catedral de Lugo. ${ }^{27}$ De sus bienes en este distrito nos informa el regalo que hizo el conde Muninus Ruderiquiz en 1074 a $\mathrm{D}^{\mathrm{a}}$. Ilduara, su segunda mujer. Este incluyó:

...Alia uilla uocitata Seruilam que est cum adjunctionibus et cum criatione per suis terminis antiquis, Sancto Iacouo de Inter Ambas Aquas cum suas ajacentias et prestationes, Monte Auto cum adjunctionibus et criatione sicuti in suis scriptis resonat. ${ }^{28}$

Veinte años más tarde, su hijo, Suarius Munionis, ofreció una gran donación a la catedral de Lugo en la que figuraban fracciones de las posesiones en Entrambasaugas, Montouto y Sirvián, y la tercera parte de San Cristobo, hoy Santiago de Gomelle:

In cauto de Luco et circa, sextam partem Sancte Eolalie et uillam que ibi est, sextam de Ermulfi, sextam de Roboreto, de Sancto Iacobo de Inter Ambas Aquas duodecimam cum adiunctionibus et familia, de Monte Alto duodecimam, de Seruilani sextam, de Sancto Christoforo tertiam. ${ }^{29}$

Partes importantes de este patrimonio también pasaron al monasterio de Ferreira de Pallares, íntimamente relacionado con esta familia. El monasterio fue reformado por los hermanos de Suarius Munionis, el conde D. Rodrigo Múñiz y Da . Elvira Múñiz, y el marido de ésta, D. Pay Gómez de Carrión. En 1129, Alfonso VII estableció los términos de su

\footnotetext{
${ }^{26}$ Sancta Maria de Tramonte, AHN Clero 1090/1 (10.I.1263); Sancti Vireximi de Bazar, 1092/4 (25.XII.1273).

${ }^{27}$ Sobre este linaje: J. de Salazar Acha, «Los descendientes del conde Ero Fernández,» Galicia en la Edad Media... (1990), 73-8; sobre el monasterio de Ferreira, J. A. Rey Caiña, «La abadía de Ferreira de Pallares desde 898 hasta 1300,» Cuadernos de Estudios Gallegos XXXIV (1983), 89-115.

${ }^{28}$ AHN Clero 1082/6 (13.XII.1074)

${ }^{29}$ AHN Cód. 417B, f. 133; García Conde y López Valcárcel (1991), 151-55.
}

"CUADERNOS DE ESTUDIOS GALLEGOS", Tomo XLIII, Fascículo 108, Santiago 1996. 
coto en un diploma concedido conjuntamente al monasterio y a la condesa $D^{a}$. Maior Ruderici, la hija de D. Rodrigo Múñiz. ${ }^{30}$ Hacia el noreste, los términos incluyeron la actual parroquia de Pradeda:

...per illum montem qui est super Nadali, et per montem de Paramio, et per Vilar de Infantionibus, et inde ad perariam de Palatios, et per portum de Agre Longo, et inde ad Romariz, et per ganderam de mamoas fornatium, et per Pennam Ruuiam, et per super riuulum, et inde ad pontem curuum, et per ganderam de Meyxaboy... ${ }^{31}$

Fuera del coto, el monasterio recibió de la condesa $\mathrm{D}^{\mathrm{a}}$. Fronili Fernandi, hija de $\mathrm{D}^{\mathrm{a}}$. Maior Ruderici, la cuarta parte de la iglesia de Entrambasaugas y la heredad de Penela en $1187 . .^{32}$

El valor de las transacciones en que participaron miembros de la familia señala la importancia de sus posesiones en esta zona en el último tercio del siglo XII. En 1171, Petrus Moniz, hijo del conde D. Munio Peláez, y su esposa, María Rodriguiz, vendieron sus heredades en la parroquia de Sirvián, tanto laicas como eclesiásticas, a su yerno, Sancius Ueremudiz, y su hija, Sancia Pedriz, por la elevada suma de quinientos sueldos. ${ }^{33}$ Diez años más tarde, otro hijo, Garsia Petri, vendió la mitad de tocius...ville Sancti Iohannis de Mera (Alto), que había heredado de su padre, por cien maravedís. ${ }^{34}$ La importancia de los bienes es subrayada tanto por el precio como por la porción de la villa, una mitad, la cual contrasta con la intensa fragmentación experimentada por muchas villas ya a finales del siglo XII. La presencia de estos documentos en el archivo

${ }^{30}$ La reforma fue mencionada en un texto de la segunda mitad del siglo XIII: AHN Clero 1096/21, publicado por de Salazar Acha (1990), 85-86. El diploma real —una copia del siglo XIII - lleva la fecha equivocada de Era 1147 (1109): AHN Clero 1082/ 8 (6.I.1129); Sánchez Belda (1953), 100; Lucas Alvarez, «Las Cancillerías Reales (11091230),» El Reino de León en la Alta Edad Media, V, León 1993, 131.

${ }^{31}$ Nadali fue un lugar en la parroquia de Zolle: AHN Clero 1086/21 (22.VI.1254). Vilar de Infantionibus - hoy Vilar de Infanzós- y Meyxaboy son lugares en las parroquias actuales de Pradeda y Guntín respectivamente

${ }^{32}$ AHN Clero 1082/15, 16 (10.II.1187), cfr. n. 100.

${ }^{33}$ AHN Clero 1325F/4 (20.X.1171). Los confirmantes destacados y la identidad del escriba, Vuilielmus...Coriensis dictus, sugieren que el documento fue hecho en la corte en camino hacia Extremadura. Para el itinerario del rey: J. González, Regesta de Fernando II, Madrid 1943, 96-97.

${ }^{34}$ AHN Clero 1325G/10 (29.V.1181).

"CUADERNOS DE ESTUDIOS GALLEGOS", Tomo XLIII, Fascículo 108, Santiago 1996. 
de la catedral indica que las propiedades pasaron a la sede. Es de suponer que la expansión del coto y el fortalecimiento de la autoridad señorial del obispo limitaron la capacidad de los nobles de explotar sus bienes dentro del coto, motivando la alienación de dichas propiedades. ${ }^{35}$

\section{FERNANDO II Y LA EXPANSIÓN DEL COTO DE LUGO}

La expansión y organización de los cotos de la catedral de Lugo y del monasterio de Ferreira fueron los hechos más destacados en esta zona en la segunda mitad del siglo XII. En 1161, Fernando II donó a Petrus Eriz su realengo en San Adrián de Monte Auto, es decir, la mitad de la iglesia, la mitad de la villa, el casal de Merina en la villa de Lamela, y las heredades pertenecientes a la villa de Montouto en las villas de Servián, Sancti Cristofori y Sancti Cipriani, en Villamediana, y en los lugares de Palagios, Treilán y Boelio.

Dono itaque tibi Marques quod et quantum regalengum habeo in Sancto Adriano de Monte Auto uidelicet medietatem ipsius ecclesie Sancti Adriani et ipsius uille Montis Alti medietatem cum aliis hereditatibus ad Montem Altum pertinentibus que sunt in uilla de Seruian et in Palagios, et in Treilan, et in Boelio, et in uilla de Lamela unum casale de Merina, et in uilla Sancti Cristofori quantum pertinet ad Montem Altum, et similiter in uilla Sancti Cipriani quantum est ius Montis Alti, et in Uilla Mediana quantum est de iure Montis Alti. ${ }^{36}$

${ }^{35}$ En 1178, Fernando II extendió los fueros concedidos a la ciudad de Lugo al distrito de Mera y estableció que los habitantes del coto fueran vasallos del obispo: Archivo de la Catedral de Lugo, lib. X, nos. 15, 16; Sánchez Belda (1953), 179.

Los documentos de Fernando II están catalogados en las obras de González (1943), Sánchez Belda (1953) y Lucas Alvarez (1993). En mis notas, me limito a citar los originales o copias medievales y las discusiones más fiables - normalmente la de Sánchez Belda - de los citados catálogos sin corregir los numerosos errores de fechas, citaciones y transcripciones de algunas de estas colecciones

${ }^{36}$ Archivo de la Catedral de Lugo, lib. X. no. 8; AHN Cód. 1043B, f. 19v-20r; Sánchez Belda (1953), 148; De Petrus Eriz, llamado Marques, no sabemos más. No fue tratado en M. M. Villa Oliveros, «Las donaciones de Fernando II de León: un proyecto para crear una estructura política en el Reino de León,» Archivos Leoneses XLII (1988), 51-82.

"CUADERNOS DE ESTUDIOS GALLEGOS", Tomo XLIII, Fascículo 108, Santiago 1996. 
En el lugar actual de Montouto se conserva una capilla de San Adrián, y las cinco villas corresponden a las cinco parroquias colindantes del distrito, ya que villa Sancti Cristofori se refiere a la parroquia de Gomelle por su antigua advocación y villa Sancti Cipriani a la de San Cibrao de Monte de Meda. En cambio, dos lugares designados simplemente por sus topónimos han desaparecido y el de Treilán subsiste como una mera localidad de la actual parroquia de Lamela.

La inclusión del privilegio real en el Tumbo Viejo es indicio de que las posesiones pasaron pronto al patrimonio episcopal. De hecho, los diplomas reales y las bulas papales atestiguan la expansión del coto lucense en esta misma zona en los años siguientes. En 1167, Fernando II lo extendió a todo el territorio comprendido entre el coto de Ferreira de Pallares y el antiguo coto de la catedral, describiéndolo así:

Sanctum Michaelem de Constanti quomodo diuidit cum Lausada et cum Castello; et quomodo diuidit cum cauto de Ferraria et cauto de Sancto Felice de Heremo; et uadit per Cotorones et concluditur in cauto antiquo de Retorta. ${ }^{37}$

Las confirmaciones papales son más explícitas en su descripción de la ampliación del coto. En una carta al obispo Juan, Alejandro III confirmó las donaciones de Fernando II:

quicquid iuris habuit in monasterio et cauto de Deomondi et in cauto monasterii de Athan; et ad ampliacionem cauti in terra de Ferraria quicquid iuris habuit in xii ecclesiis tuo cauto contiguis et hereditatibus familiis et uoce regali; et in terra de Aguyar quicquid iuris habuit in ecclesia de Teyxero cum uoce regali et familia et in Monte Toto de Labio; et tertiam partem monete que in ciuitate tua facta fuerit. ${ }^{38}$

Al confirmar la ampliación del coto in terra de Ferraria, la carta se refiere a doce iglesias, pero esta versión, citada del Tumbo Viejo, discrepa de las dos originales del bulario de la catedral. ${ }^{39}$ En éstas, se habla de once

${ }^{37}$ Archivo de la Catedral de Lugo, lib. X, no. 11 (11.VII.1167); AHN Cód. 1043B, f. 21v (15.VII.1167); Sánchez Belda (1953), 162.

${ }^{38}$ AHN Cód. 1043B, f. 43v-44r (30.VI.1170?).

${ }^{39}$ Archivo de la Catedral de Lugo, lib. XI, nos. 2 (30.VI.1170?), 3 (7.VII.1170?).

"CUADERNOS DE ESTUDIOS GALLEGOS", Tomo XLIII, Fascículo 108, Santiago 1996. 
iglesias y el uso de la palabra, undecim, dificulta la atribución de la variante del Tumbo Viejo a un simple descuido del copista. En todo caso, antes de identificar las iglesias, debemos averiguar si pertenecieron a la ampliación del coto en la zona de Constante en 1167.

La data de la carta papal no incluye el año, pero ha sido atribuída a $1178 .^{40}$ No obstante, el lugar de su expedición - Veroli - establece que fue escrita en 1170 durante la única estancia de Alejandro III en Veroli, ${ }^{41}$ Esta fecha concuerda con el contenido porque todas las concesiones reales citadas que pueden ser fechadas son anteriores a 1170. Me refiero a la concesión en 1158 de la tercera parte de la moneda acuñada en Lugo, la del coto de Atán en 1164, y la de Diomondi entre 1164 y $1170 .{ }^{42}$ Por otra parte, la fecha de 1170 aclara su relación con el privilegio otorgado por el legado papal, el Cardenal Jacinto, en $1172 .{ }^{43}$ Este omite los privilegios de la carta anterior, limitándose a citar los que fueron concedidos a partir de 1170, como la donación real de la iglesia de Ver en 1172 y la cesión de la de San Salvador de Sarria por el conde de Sarria en $1171 .{ }^{44}$ Así que es muy

${ }^{40}$ La fecha de 1178 fue propuesta por Cañizares (Colección diplomática..., t. II, no. 285) y aceptada por Vázquez Saco, «Iglesias románicas...San Pelagio de Diomondi,» Boletín...de Lugo II (1946), 272.

${ }^{41}$ P. Jaffé, Regesta Pontificum Romanorum, Leipzig 1888, II, 232-38

${ }^{42}$ La concesión de la moneda: AHN Cód. 1043B, f. 18v-19r (19.II.1158), publicada en España Sagrada, XLI, ap. xiii, pp. 319-20; Sánchez Belda (1953), 141. El coto de Atán: Archivo de la Catedral de Lugo, lib. X, no. 10 (13.XII.1164); AHN Cód. 1043B, f. 20rv; publicada en extracto en, España Sagrada, XLI, ap. xiv, pp. 320-21; Sánchez Belda (1953), 156. Fernando II concedió el monasterio de Diomondi a Fernandus Odoarii y Therasia Muniiz en 1164: AHN Cód. 1043B, f. 20r (14.III.1164); Sánchez Belda (1953), 153-54. Fernandus Odoarii murió hacia 1169 , pero la iglesia no fue incluida en su testamento: Archivo de la Catedral de Ourense, Escrituras XVII, 104. Una inscripción de 1170 conmemora la colocación del dintel de la portada occidental de la iglesia románica cuya relación con la catedral de Lugo es muy importante: J. D’Emilio, Romanesque architectural sculpture in the diocese of Lugo, east of the Miño, Ph.D thesis, University of London (1988), 179-95. Su construcción debió haber acompañado a su cesión a la catedral de Lugo entre 1164 y 1169.

${ }^{43}$ Archivo de la Catedral de Lugo, lib. XI, no. 5 (20.V.1172); AHN Cód. 1043B, f. 44rv.

${ }^{44}$ San Salvador de Sarria: AHN Clero 1325E/23 (20.II.1171); publicado en España Sagrada, XLI, ap. xv, pp. 322-23; citada por Fletcher con una fecha equivocada de 1170 (1978), 170-71. Ver: Archivo de la Catedral de Lugo, lib. X, no. 12 (1.V.1172); AHN Cód. 1043B, f. 21 rv (1.V.1202); publicado en España Sagrada, XLI, ap. xvi, pp. 324-35; Sánchez Belda (1953), 168-9.

"CUADERNOS DE ESTUDIOS GALLEGOS", Tomo XLIII, Fascículo 108, Santiago 1996. 
probable que las once iglesias de la carta papal de 1170 pertenecieran a la ampliación del coto en el distrito de Constante en 1167.

Para identificar las iglesias debemos tener en cuenta las bulas de 1179 y $1185 .{ }^{45}$ El privilegio solemne de 1185 del papa Lucio III ofrece la relación más explícita, nombrando las iglesias incluídas en la ampliación del coto antiguo de la catedral. Según la versión del Tumbo Viejo, éstas son:

preterea ecclesias de palliariares $<$ sic $>$ que in augmentum ueteris cauti lucensi sunt ecclesie asignate. Videlicet ecclesiam Sancte Marie de Coheses, Sanctum Iohannem de Campo, ecclesiam Sancti Mametis de Framir, ecclesiam Sancti Martini de Castro, ecclesiam Sancti Iacobi de Ferron cum familiis et directuris suis et uoce regali; ecclesiam Sancti Michilis de Costanti, ecclesiam Sancti Martini de Meda, ecclesiam Sancti Cipriani, ecclesiam de Peraredo, ecclesiam Sancti Christofori, ecclesiam de Lamela, ecclesiam de Uilla Mediana, hereditatem Montis Outi, ecclesiam Sancti Iacobi Inter Anbas Aquas, ecclesiam de Uilla Maiori, ecclesiam de Nigral, ecclesiam Sancti Martini de Caabogi, ecclesiam de Teixeiro, ecclesiam de Ameneda, ecclesiam Sancti Christofori de Barreto, ecclesiam de Gaudaar, et ecclesiam Sancti Salvatoris de Riman. cum cautis et familiis et uoce regali. ${ }^{46}$

Estas iglesias formaron parte de varias ampliaciones del coto concedidas por Fernando II. Las cinco primeras corresponden a las parroquias contiguas de Coeses, Campo, San Mamede de Ribas de Miño, San Martiño de Piñeiro y Santiago de Ferroi. De éstas, Coeses ya estaba incluída en la bula de Alejandro III de 1179, las demás fueron donadas a la sede por la reina $\mathrm{D}^{\mathrm{a}}$. Teresa entre 1178 y $1180 .{ }^{47}$ De las últimas seis

${ }^{45}$ La bula de 1179: Archivo de la Catedral de Lugo, lib. XI, no. 4 (15.VI.1179); AHN Cód. 1043B, f. 42v-43v. La bula de 1185: AHN Cód. 1043B, f. 44v-45v (2.VIII.1185); García Conde y López Valcárcel (1991), 219-22. No he tenido oportunidad de transcribir el original que está entre los pergaminos sueltos del Archivo de la Catedral de Lugo.

${ }^{46}$ AHN Cod. 1043B, f. 45r.

${ }^{47}$ La donación de la reina fue confirmada por Fernando II en 1180: AHN Cód. 1043B, f. 22rv (6.II.1180); publicada con fecha errónea de 1181 en España Sagrada, XLI, ap. xx, pp. 334-35; Sánchez Belda (1953), 183. Fernando II había dado las iglesias a la condesa $\mathrm{D}^{\mathrm{a}}$. Teresa en 1178 antes de casarse: Archivo de la Catedral de Lugo, lib. X, no. 14 (VII.1178); AHN Cód. 1043B, f. 21v-22r; Sánchez Belda (1953), 179-80.

"CUADERNOS DE ESTUDIOS GALLEGOS", Tomo XLIII, Fascículo 108, Santiago 1996. 
iglesias, San Martiño de Caabogi (Caboi) aparece por primera vez, pero la villa de Cahaboge en Rábade fue incluida tanto en la confirmación real de privilegios anteriores en 1178 como en la bula de 1179 basada en el mismo diploma real ${ }^{48}$. Las demás integraron unas ampliaciones sucesivas del coto hacia el noreste y el este. ${ }^{49}$

Las diez iglesias restantes debieron haber formado parte de las once iglesias de la ampliación del coto confirmada por el Papa en 1170. La mayoría se corresponden con las parroquias actuales: Constante, San Martiño de Monte de Meda, San Cibrao de Monte de Meda, Lamela, Vilameá, Entrambasaugas y Vilamaior de Negral. San Cristobo es la parroquia actual de Santiago de Gomelle, y la iglesia de Peraredo coincide con la de Santiago de Pradedo suprimida en el arreglo parroquial de $1890 .^{50}$ La iglesia de Nigral se corresponde con la parroquia actual de Sta. María de Pacio, contigua a la de Vilamaior de Negral. ${ }^{51}$ De las diez iglesias, las ocho primeras se hallan claramente dentro de los límites señalados en la ampliación del coto en 1167. La confirmación real de 1178 relacionó Vilamaior y Nigral con la ampliación de 1167 en la zona contigua, y su pertenencia a esta concesión explicaría, en parte, la referencia a las once iglesias en la carta papal de 1170.

${ }^{48}$ El privilegio real de 1178: Archivo de la Catedral de Lugo, lib. X, no. 17 (7.X.1178); AHN Cód. 1043B, f. 22v-23r; publicado en España Sagrada, XLI, ap. xix, pp. 330-33; Sánchez Belda (1953), 180.

${ }^{49}$ Estas iglesias corresponden a las parroquias actuales de Sta. María de Teixeiro, Santiago da Meda, San Andrés de Barredo, Sta. María de Gondar y San Pedro de Romeán

${ }^{50}$ García Conde y López Valcárcel (1991), 794-5.

${ }^{51}$ En 1138, un documento de Carracedo localizó Sancti Martini de Ferraria (Ponteferreira) inter monasterio Sancti Georgii (Augas Santas) et Sancta Maria de Negral: A. Quintana Prieto, «Monasterios de Corullón», Temas Bercianos: Los monasterios de El Bierzo Bajo, Ponferrada 1983, 444, 491. Un documento de 1223 consigna la donación al monasterio de Pallares de domus nostra que vocatur hospitale de villa nova que vocatur Nigral...sub aula Sancte Marie de Nigral para la fundación de un albergue, AHN Clero, 1083/12 (13.VIII.1223). Quizás esa casa dió el nombre de Pacio a la parroquia, ya que en 1410 se citó el pazo de Negral en la parroquia de Santa María do Pazo: AHN Cód. 417B, f. 53r. Otro documento de 1223 localiza un solar de la misma parroquia in burgum de villanova qui vocatur Negral: AHN Clero, 1083/13 (13.VIII.1223). En la parroquia actual de Sta. María de Pacio, hay un lugar llamado Burgo atravesado por el río do Burgo do Negral.

"CUADERNOS DE ESTUDIOS GALLEGOS", Tomo XLIII, Fascículo 108, Santiago 1996. 
La undécima iglesia no puede ser identificada con certeza, pero los documentos sugieren tres posibilidades: San Adrián de Montouto, San Estebo de Trastulfe y San Xurxo de Constante. La bula de 1185 incluyó la heredad de Montouto sin mencionar la iglesia de San Adrián. La omisión puede ser una primera señal de una condición anómala que resultaría en su exclusión de la red parroquial. En 1202, San Estebo de Trastulfe aparece localizada en el coto lucense en una descripción de propiedades:

in Sancto Stefano de Transtulfi...que ecclesia...est in vestro cauto inter Sanctum Iacobum de Interambasaquas et Platanetam. sub Monte de Meda. ${ }^{52}$

Esta iglesia desaparecida corresponde al lugar del mismo nombre en la parroquia actual de Vilameá, y puede ser identificada con la capilla de San Estebo en la antigua parroquia de Pradedo. ${ }^{53}$ San Xurxo aparece relacionada con San Miguel de Constante en varios documentos de los siglos XII y XIII, pero, como veremos, estaba ya en vías de desaparición. La localización de las tres iglesias en el territorio del coto ampliado sugiere que cualquiera de ellas podría haber sido la undécima iglesia de la carta papal y la duodécima del Tumbo Viejo. La condición precaria de estas tres iglesias explicaría tanto una omisión en la carta papal como una adición en la copia del Tumbo Viejo.

\section{LA ORGANIZACIÓN Y ADMINISTRACIÓN DEL COTO DE LUGO}

En cualquier caso, buena parte del distrito de Monte de Meda fue integrado en el coto de la catedral en 1167, y la lista de iglesias en la bula de 1185 coincide con la organización parroquial que duró hasta el siglo pasado. La solicitación de la confirmación papal de los privilegios reales fue sólo un paso hacia la consolidación y administración del nuevo coto. En los años siguientes, el obispo estableció acuerdos con el vecino monasterio de Ferreira de Pallares, rodeó el perímetro del coto con torres

${ }^{52}$ Se conservan ambas partes de la carta partida: AHN Clero 1326C/28, 1082/19 (25.VI.1202).

"CUADERNOS DE ESTUDIOS GALLEGOS", Tomo XLIII, Fascículo 108, Santiago 1996. 
guarnecidas por sus vasallos, e impuso su autoridad fiscal y jurídica a través de los merinos y sayones.

En 1202, el obispo D. Rodrigo II y el abad de Ferreira acordaron un cambio de posesiones en sus respectivos cotos. El obispo cedió una heredad en la parroquia de Pradeda, y recibió las posesiones de la abadía en la de Transtulfi. ${ }^{54} \mathrm{El}$ propósito fue concentrar las posesiones, evitando así los conflictos entre vecinos y facilitando la explotación de sus haciendas. En 1241 el abad de Ferreira vendió al obispo otras heredades en el coto lucense, esta vez en las parroquias de Sirvián y Campo. ${ }^{55}$

Al mismo tiempo, el obispo procuró defender el coto, y documentos de 1178 y 1204 mencionan las torres de San Fiz de Robra y San Xoán do Campo respectivamente, ésta recién construida por un vasallo del obispo, Rudericus Ruderici miles de Paliaris, en la zona que había pasado a la jurisdicción episcopal en $1180 .{ }^{56}$ En el distrito de nuestro estudio, el obispo admitió a D. Fernandus Munionis en la torre de Sirvián como vasallo en 1203, y el caballero juró su fidelidad y prometió defender el castillo. ${ }^{57}$ Los documentos no nos informan más que de su nombre, pero podría ser el jóven D. Fernandus Munionis de Rodeiro, de la familia de los patrones del monasterio de Ferreira. ${ }^{58}$ En 1251, la torre de Sirvián pasó a D. Petrus Arie de Parga, hijo de D. Arias Petri de Parga y sobrino del obispo D. Michael. ${ }^{59}$ El caballero cedió al obispo sus heredades en Pias y

\footnotetext{
${ }^{53}$ N. Rielo Carballo notó que la capilla de San Estebo fue deshecha en 1933: Valiña Sampedro et al., VI (1983), 300.

${ }^{54}$ cit. n. 51

${ }^{55}$ AHN Clero 1328A/18 (20.VII.1241).

${ }^{56}$ Robra: AHN Clero 1325F/27 (1178); Campo: 1326D/22 (3.VI.1204). La iglesia de Campo formó parte de la donación de la reina $\mathrm{D}^{\mathrm{a}}$. Teresa, cit. n. 46.

${ }^{57}$ AHN Clero 1326D/14 (1.VIII.1203).

${ }^{58} \mathrm{D}$. Fernandus Munionis de Rodeiro, hijo de Munio Fernandi, probablemente fue el Fernandus Munionis miles que atestiguó dos documentos importantes de 1196: AHN Clero 1326A/21 (20.V.1196), 23 (14.VII.1196). Entre 1204 y 1209 aparece en varios documentos como teniente de Monterroso: 1082/20 (1204), 22 (6.I.1209); Tumbos...de Sobrado (1976), II, doc. 263, p. 263 (19.IV.1206); J. González, Alfonso IX, Madrid 1944, II, doc. 233 (2.IV.1208), pp. 321-22. Entre 1208 y 1227, aparece como teniente de Pallares: 1082/21 (18.I.1208), 1083/8 (VII.1219), 21 (13.VI.1227). Se casó con D ${ }^{\mathrm{a}}$. Teresa Rodriguez, 1083/12, 13 (13.VIII.1223), y fue el padre de D. Munio Fernández de Rodeiro y D. Rodrigo Fernández. El hecho de que su mujer hiciera una compra sin él en Nigral, donde tenían propiedades, sugiere que estaba muerto en 1228: 1241/19 (24.IX.1228).

${ }^{59}$ AHN Clero 1328F/4 (24.IX.1251).
}

"CUADERNOS DE ESTUDIOS GALLEGOS", Tomo XLIII, Fascículo 108, Santiago 1996. 
Tirimol, y se comprometió a tener el castillo durante su vida y defender al obispo. Tres años más tarde, el obispo añadió la cesión de su propiedad en la iglesia de Sirvián con la condición de que D. Petrus Arie la devolvería a la sede después de su muerte con cualquier propiedad que comprara o ganara en la misma iglesia. ${ }^{60}$

En la data de un documento de 1251 se relaciona otro oficial con la torre de Sirvián: maiordomi episcopi Petri Ruderici de terra et de torre de Serviam. ${ }^{61}$ Con la organización del nuevo coto en el siglo XIII, se multiplicaron los merinos encargados de su administración. Los primeros merinos conocidos, como Garsia Nuniz, citado entre 1165 y 1177 , actuaron tanto en la ciudad como en el coto. ${ }^{62}$ En 1189, ya aparece un merino in Burgo Novo. ${ }^{63}$ Otros obtuvieron el título en distritos rurales, como los de Pedreda o Piugos, y con el avance del siglo XIII, las datas y listas de testigos de los documentos locales nos permiten seguir las carreras de los merinos de varias circunscripciones. ${ }^{64}$

\section{EL MERINO RUDERICUS PETRI BAZARIUS}

Entre los primeros que se destacaron estuvo Rudericus Petri Bazarius, un merino estrechamente ligado al distrito de Monte de Meda. Rudericus Petri actuó como merino entre 1194 y 1243, y confirmó documentos hasta 1246. En 1220, hizo una donación importante a la catedral con su mujer, Maria Pelagii, entregando sus propias personas y sus posesiones en más de doce parroquias y derechos eclesiásticos en nueve de ellas. Su larga tenencia nos ofrece la oportunidad de trazar la carrera de un merino y considerar las relaciones entre las merindades y los territorios de las parroquias. Al mismo tiempo, la gran donación nos ilumina acerca de las

${ }^{60}$ AHN Clero 1328H/3 (30.I.1254).

${ }^{61}$ AHN Clero 1086/14 (17.IV.1251).

${ }_{62}$ Maiorinus in civitate et cauto: AHN Clero, 1325E/18 (17.VII.1168), 19 (11.I.1169), 1126/19 (20.VIII.1171). Fué titulado maiorinus, maiordomus o pretor en varios documentos de AHN Clero 1325E y 1325F, y estos términos, evidentemente, fueron equivalentes en los documentos lucenses

${ }^{63}$ AHN Clero, 1325H/9 (16.II.1189).

${ }^{64}$ Petrus monacus pretor de Pingus: AHN Clero 1325F/5 (19.III.1172); Petrus Cangas maiorinus in Pedreda: 1325G/15 (13.II.1183).

"CUADERNOS DE ESTUDIOS GALLEGOS", Tomo XLIII, Fascículo 108, Santiago 1996. 
relaciones entre su patrimonio familiar y el ejercicio del oficio de merino, y su posesión de porciones de varias iglesias del distrito nos introduce al sistema de iglesias propias.

En 1194, Michael Lupi empeñó unas casas en Reisendi a Rudericus Petri, el merino del obispo, que volvió a ser citado como maiordomus episcopi tres años más tarde en una venta particular en Piugos. ${ }^{65}$ En 1200, la data de la venta del casalde Baceiroo tituló a Rudericus Petri de palacio como maiordomus illius uille in qua est hereditas, y fue citado como teniente de la tierra en una venta en la parroquia de Fingon (Cuiña) en $1202 .{ }^{66}$ El título de palacio apunta a su vinculación con la casa episcopal, y un documento episcopal de 1204 refiere a unas parcelas compradas por Rudericus Petri que el obispo describió como quondam maiorini mei, señalando una separación temporal del cargo. ${ }^{67}$

A partir de 1210, Rudericus Petri llevó el apodo de Bazarius, debido, sin duda, a su relación con el casal de Baceiroo probablemente en Bazar donde las propiedades, heredadas de su padre, encabezaron la lista de sus posesiones en la donación de $1220 .^{68}$ Entre 1210 y 1243 , Rudericus Petri Bazarius apareció con frecuencia en las datas o entre los testigos de documentos de las parroquias del coto al oeste del Miño. Al principio se le describe como teniente del obispo en un distrito determinado. ${ }^{69}$ A partir de 1224 , se le titula merino o mayordomo, términos equivalentes en esta

${ }^{65}$ AHN Clero 1326A/11 (9.XII.1194), 1326B/7 (20.XII.1197). Reisendi corresponde a un lugar relacionado con Saamasas en varios documentos. Uno de los testigos fue Rudericus Petri de la canonica, quizás el merino mismo.

${ }^{66}$ AHN Clero 1326B/22bis (16/17.XII.1200), 1326C/25 (8.V.1202).

${ }^{67} \mathrm{Tal}$ lenguaje suele indicar el fallecimiento del aludido, pero en este caso, las continuidades con la carrera del merino citado a partir de 1210 aconsejan otra interpretación.

${ }^{68}$ Merece notarse que Martinus Diaz de Baceirou fue uno de los testigos del documento de 1202 en el que Rudericus Petri de Palacio fue mencionado en la data: AHN Clero 1326C/25 (8.V.1202). De hecho, varios documentos romancearon el apodo de Rudericus Petri como Baceiro. En otros casos, Rudericus Petri fue citado sin el apodo.

${ }^{69}$ AHN Clero 1326E/27 (19.XII.1210), tenentis Tauoeli (en Orbazai) de manu episcopi; 1326G/6 (8.VII.1213), tenentis Gomaeli ex parte episcopi; carp. 1327A/7 (15.VI.1218), maiorini tenentis terram ipsam de manu episcopi (una transacción in Esperanti in filigrisia Sancte Eolalie Alta); 1327B/1 (11.VIII.1221), tenentis terram ipsam (Santiago de Piugos); 1083/16 (10.III.1224), tenentis terram ipsam (San Martiño de Monte de Meda).

"CUADERNOS DE ESTUDIOS GALLEGOS", Tomo XLIII, Fascículo 108, Santiago 1996. 
documentación..$^{70}$ Podemos inferir el ámbito de su jurisdicción por la distribución geográfica del número creciente de documentos que incluyen los merinos en sus datas.

Entre mayo de 1224 y enero de 1225, Rudericus Bazarius actuó como merino episcopal en la ciudad de Lugo donde sucedió a Petrus Iohannis. ${ }^{71}$ En el coto, no es tan fácil precisar la jurisdicción de los merinos, su duración en el cargo, o las relaciones entre los merinos de diversos distritos, debido a la dispersión geográfica y cronológica de los documentos. De todas formas, el papel dominante de los notarios de Lugo, Pelagius Ueremudi (1224-1235) y Fernandus Pelagii (1235-1271), a mediados del siglo XIII impuso una mayor uniformidad en los criterios para la inclusión de un merino en las datas de los documentos. Entre 1230 y 1243, Rudericus Bazarius llevó el título en catorce documentos que trataron de propiedades en las parroquias de Sta. María Alta, San Vicente de Muris (Burgo), Sta. Cruz de Retorta, Sirvián, Lamela, San Martiño de Monte de Meda, Constante, San Xoán de Campo y Soñar. ${ }^{72}$ Entre ellas, las parroquias de Alta, Retorta, Soñar y Campo se hallan al margen geográfico del grupo, y un análisis de los documentos de estas parroquias que lo citan como merino confirma que se situaron al margen de su jurisdicción.

Circunstancias especiales explican la mención de Rudericus Bazarius en los documentos de Soñar y Campo. En Soñar, fue citado en una venta hecha por Pelagius Pelagii dictus Baceirus, probablemente un familiar suyo, cuyo protagonismo podría haber motivado al escriba a incluirlo en

\footnotetext{
${ }^{70}$ El notario lucense, Pelagius Veremudi (1224-1235), empleaba ambos, favoreciendo el de maiorinus. Su sucesor, Fernandus Pelagii (1235-1271), empleó maiordomus exclusivamente.

71 AHN Clero 1327B/17 (4.V.1224), 17bis (8.VII.1224), 19 (19.XI.1224), 20ter (30.I.1225). Petrus Iohannis ocupó el cargo en 1221 y 1222 según las datas de cinco documentos en 1327A y 1327B. Rudericus Bazarius fué sustituído por Munio Martini que ya había ocupado el cargo en 1212 - 1326F/10 (26.I.1212), 17 (27.V.1212) - y volvió a ocuparlo entre 1225 y 1238 según las datas de 26 documentos en 1327B, C, D, E, F, G y H.

72 AHN Clero 1327D/17 (1.II.1230), 25 (16.IV.1230), 1327E/3 (23.V.1230), 4 (27.V.1230), 25 (24.V.1232), 1084/12 (25.IX.1233), 13 (28.IX.1233), 1327G/2 (24.V.1234), 3 (20.VI.1234), 1327H/18 (7.V.1238), 1328A/3 (29.III.1240), 18 (20.VII.1241), 1066/19 (1.XII.1241), 1328B/17 (17.X.1243). El merino Rudericus Petri citado en un documento de Bóveda podría ser otra persona: 1327D/16 (26.I.1230).
}

"CUADERNOS DE ESTUDIOS GALLEGOS", Tomo XLIII, Fascículo 108, Santiago 1996. 
la data. ${ }^{73}$ En otra transacción se combinaron propiedades en Soñar y San Martiño de Monte de Meda, y la data de una venta de propiedades en Campo y Sirvián lo citó en 1241 como maiordomus in Mera, un título relacionado con sus poderes en Sirvián. ${ }^{74}$ En los documentos de Alta y Retorta, Rudericus Bazarius compartió el título, otra señal de los límites de su jurisdicción. En 1230, fue titulado merino in Mera con Pelagius Ueremudi en las datas de cuatro ventas de porciones de la villa de Lodeiro en Alta, y, en 1234, la data de otra venta en la misma villa lo asoció con Erus Petri en el oficio de merino. ${ }^{75}$ En el mismo año, éstos volvieron a aparecer juntos en la data del único documento de Retorta que citara a Rudericus Bazarius como merino, quizás por su participación como confirmante de la transacción. ${ }^{76}$

Si la asociación de Rudericus Bazarius con Erus Petri en 1234 se debe, en parte, a la localización de las transacciones en Retorta y Alta a los márgenes de su autoridad, podría también indicar una interrupción en su actuación, dado que Erus Petri fue citado en el mismo año como merino en un documento de Gomelle, una parroquia del distrito en que Rudericus Bazarius solía ejercer el cargo. ${ }^{77}$ En todo caso, Rudericus Bazarius atestiguó este documento y continuó como merino entre 1238 y 1243, según documentos de Lamela, Muris (Burgo), Sirvián y Constante. Atestiguó dos foros episcopales en 1246, pero murió poco después como se deduce de la citación insólita de una mujer, Maria Pelagii de Fargaoze - seguramente su esposa - como maiorina en la data de una venta particular de heredades en Constante y Castelo en enero de $1247 . .^{78}$

73 AHN Clero 1327E/25 (24.V.1232). Uno de los testigos fue Pelagius Petri presbyter de Paderni, un lugar de la parroquia de Bazar.

${ }^{74}$ AHN Clero 1084/12 (25.IX.1233); 1328A/18 (20.VII.1241).

75 AHN Clero 1327D/17 (1.II.1230), 25 (16.IV.1230), 1327E/3 (23.V.1230), 4 (27.V.1230), 1327G/2 (24.V.1234).

${ }^{76}$ AHN Clero 1327G/3 (20.VI.1234). Esta vez Erus Petri fue citado como domnus Erus, pero lleva este título únicamente cuando no se emplea el nombre paterno. El merino Simon Iohannis, llamado alternativamente domnus Simon, ofrece un caso similar, cfr. n. 81 y las observaciones sobre el uso del domnus con nombres solos como un elemento de singularización dentro de la evolución de los nombres de dos elementos: P. Martínez Sopena, «La antroponímia Leonesa: un estudio del Archivo Catedral de León (8761200),» Antroponímia y sociedad: sistemas de identificación hispano-cristianos en los siglos IX a XIII, Valladolid y Santiago 1995, 162, 168

${ }^{77}$ AHN Clero 1327G/8 (8.IX.1234).

${ }^{78}$ AHN Clero 1328C/11, 12 (29.IV.1246), 1086/1 (29.I.1247). 


\section{LOS TERRITORIOS DE LAS MERINDADES}

En el segundo cuarto del siglo, los documentos de Retorta y Alta confirman su exclusión de la jurisdicción de Rudericus Bazarius, y la sucesión de los merinos en estas parroquias aclara los marcos territoriales de su autoridad. En Retorta, Erus Petri compartió el cargo con Nuno Nunonis en 1234 y volvió a ser citado al año siguiente ${ }^{79}$. Cuando la serie de documentos de Retorta continuó en 1242, Nuno Nunonis ocupaba el cargo. ${ }^{80}$ Mientras tanto, Erus Petri continuó como merino en Alta en 1239 y 1241, años en que ejercía el cargo en las parroquias vecinas de Vilachá y Veral, lo que implica una jurisdicción que incluía varias parroquias del norte del distrito de Mera. ${ }^{81}$

Las datas de documentos del tercer cuarto del siglo indican que ésta fue una de al menos dos jurisdicciones pertenecientes al distrito de Mera. Al norte, Simon Iohannis fue el único merino documentado en las parroquias de Alta, Vilachá y Vilafiz entre 1249 y 1255 , y Petrus Fernandi actuó en éstas más las vecinas de Veral y Bacurín entre 1260 y $1266 .^{82}$ Sin embargo, ninguno de ellos recibió el título de maiordomus in Mera, título que sí ostentó Pelagius Froile en 1257 según la data de un documento de la vecina parroquia de San Xoán de Alto. ${ }^{83}$ A pesar del título, su autoridad se limitó a la zona alrededor de la parroquia de Muris (Burgo) donde fue citado como merino trece veces entre 1249 y 1271, así como varias veces

\footnotetext{
${ }^{79}$ AHN Clero 1327G/12 (13.X.1234), 14 (2.I.1235). De hecho, fueron citados separadamente en las datas de dos documentos - $1327 \mathrm{G} / 4,5$ - redactados por el mismo notario en el mismo día (2.VII.1234), un hecho que nos advierte de las dificultades que presentan estas fuentes.

${ }^{80}$ Nuno Nunonis fue citado como merino en siete documentos de Retorta entre 1242 y 1253 , aunque nunca apareció como merino en otras parroquias. La serie empieza con AHN Clero 1328B/8 (1.XII.1242) y termina con 1328G/3 (1.I.1253).

81 Alta: AHN Clero 1327H/24 (21.VII.1239), 1328A/23 (7.X.1241); Vilachá: 1327F/ 11 (21.X.1233/domnus Ero), 1327H/14 (12.XII.1237), 1328A/8 (18.IX.1240), 15 (7.IV.1241); Veral: 1327H/1 (1.X.1236), 5 (23.I.1237).

${ }^{82}$ Domnus Simon o Simon Iohannis: Vilafiz: AHN Clero 1328D/19 (25.III.1249), 1328E/25 (23.V.1251); Vilacha: 1328F/5 (26.IX.1251), Alta: 1328F/18 (10.V.1252), 1086/22 (14.VII.1254), 1329A/2 (10.V.1255). Petrus Fernandi fue citado como merino trece veces en las datas de documentos de las citadas parroquias en 1329F, G, H, 1330A, C, D, F.

${ }^{83}$ AHN Clero 1329B/11 (16.VIII.1257).
}

"CUADERNOS DE ESTUDIOS GALLEGOS", Tomo XLIII, Fascículo 108, Santiago 1996. 
en la vecina parroquia de Prógalo. ${ }^{84}$

De estos casos se puede concluir que las merindades abarcaban varias parroquias y mantenían cierta integridad bajo una sucesión de merinos, coincidiendo, a veces, con los distritos acotados en distintos momentos. Aunque las datas revelan la sucesión de merinos en varios distritos y el ámbito general de su jurisdicción, las lagunas geográficas y cronológicas en la documentación nos impiden precisar con exactitud los límites de las merindades. El título de merino de Mera - poco frecuente- es uno de los pocos que sugieren un marco territorial, pero el análisis de las datas revela que el ámbito de su jurisdicción cambiaba según el ocupante del cargo.

La parquedad de las referencias en la documentación no es el único obstáculo en la determinación de los marcos de las merindades. Otras circunstancias deben tenerse en cuenta. Para empezar, las merindades episcopales en esta época están todavía empezando a tomar cuerpo como territorios fijos. Además un merino puede cambiar de jurisdicciones, acumularlas o perderlas durante una larga carrera, como la de Rudericus Bazarius, debido a que su autoridad como merino episcopal tiende a ir ligada a sus poderes como propietario. ${ }^{85}$ También hay que tener en cuenta el papel del mayordomo mayor del obispo, cuya autoridad sobrepasaba estas circunscripciones. Este fue el caso de Lupus Petri, quien pidió prestaciones de los hombres de Muris (Burgo) y Prógalo en 1256, un año en que Pelagius Froile fue citado como merino en la misma zona ${ }^{86}$. La misma naturaleza del cargo explica el hábito de los notarios de nombrar los merinos sin precisar sus jurisdicciones, dado que éstas estaban vinculadas tanto con su ocupante como con un territorio determinado. Estos territorios tardarán en alcanzar una estabilidad comparable a la de la parroquia como unidad de organización territorial.

${ }^{84}$ La serie de citaciones en Muris (Burgo) comienza con AHN Clero, 1328D/27 (30.VII.1249), y continúa al menos hasta 1330G/15 (11.I.1271). Prógalo: 1329F/6 (18.III.1260), 16 (24.IV.1260).

${ }^{85}$ Hay otros ejemplos de merinos de este distrito con importantes propiedades en las zonas de su jurisdicción. Simon Iohannis y su mujer vendieron propiedades en Vilafiz al obispo por 400 sueldos: AHN Clero 1328D/19 (25.III.1249). Petrus Pelagii, clérigo de Orbazai, vendió propiedades en Orbazai y Adai al obispo por 1000 sueldos y una cantidad de centeno: 1329G/14 (20.VII.1260). Fue citado como merino en 1330F/4 (11.IX.1267).

${ }^{86} \mathrm{AHN}$ Clero 1329A/10 (24.II.1256), publicado en E. Hinojosa, Documentos para la historia de las instituciones de León y Castilla (siglos X-XIII), Madrid 1919, doc. LXXVIII, pp. 129-33.

"CUADERNOS DE ESTUDIOS GALLEGOS", Tomo XLIII, Fascículo 108, Santiago 1996. 


\section{EL PATRIMONIO DE RUDERICUS BAZARIUS}

La gran donación de Rudericus Bazarius y su mujer nos ofrece un ejemplo de como la confluencia de los poderes públicos y privados configura las relaciones entre las parroquias de un distrito. De la importancia de esta donación deja constancia el esplendor de la carta partida preparada por el notario episcopal en $1220 .{ }^{87}$ Rudericus Bazarius donó propiedades y derechos en las parroquias de Bazar, Constante, San Xurxo, Calde, Muris (Burgo), Sta. Cruz de Retorta, San Martiño de Monte de Meda, Alta y Orbazai. Maria Pelagii, su mujer, añadió propiedades en tres parroquias nombradas explícitamente, Campo, Sta. Eulalia de Lousada y Piñeiras, y otros bienes que pueden ser localizados en las actuales parroquias de Constante, Piñeiro, Mosteiro, Mota y Mougán. El matrimonio entregó sus propias personas a la catedral, y recibió una tenencia vitalicia sobre el villar de Fargoox, derechos en Constante y una heredad con serviciales. ${ }^{88}$

Rudericus Bazarius había logrado reunir su patrimonio a través del matrimonio, la herencia y la compra. La lista comienza con sus bienes en Bazar y Paderne heredados de su padre, Petrus Ueremudi, y comprados de su tío paterno, Guterrus Ueremudi ${ }^{89}$. De sus padres heredó sus derechos y propiedades en la iglesia y parroquia de Calde, de su madre sus derechos en la iglesia y parroquia de San Vicente de Muris (Burgo). Del abuelo materno recibió una parte de un casal en Alta o en Orbazai. Al igual que sus padres, que habían reunido sus patrimonios en las parroquias vecinas de Bazar, Calde y Muris (Burgo), él repitió el proceso en otro escenario al casarse con Maria Pelagii, dueña de importantes propiedades en la vecina zona de Pallares.

La localización de las propiedades confirma los intereses del donante en las parroquias en que actuó como merino. Antes de la donación, su

${ }^{87}$ AHN Clero 1327A/15, 16, 17 (13.IV.1220).

${ }^{88}$ Se puede comparar la relación de familiaritas entre matrimonios e instituciones eclesiásticas investigada por J. Orlandis, «Traditio Corporis et Animae, laicos y monasterios en la alta edad media española,» Estudios sobre instituciones monásticas medievales, Pamplona 1971, 298-302, 329-31, 335-38.

${ }^{89}$ Petrus Ueremudi fue citado como merino de la ciudad de Lugo en 1178,1179 y 1183, y en el Burgo Novo cuatro veces entre 1202 y 1220 , pero la evidencia no permite una identificación definitiva con el padre de Rudericus Bazarius.

"CUADERNOS DE ESTUDIOS GALLEGOS", Tomo XLIII, Fascículo 108, Santiago 1996. 
acción se concentró en las afueras de Lugo y las parroquias vecinas como Saamasas, Piugos y Cuiña, pero en 1200 ya se le relaciona con el casal de Baceiroo, seguramente en Bazar, el núcleo del patrimonio de su padre y el lugar que le dió su apodo. En sus últimos años ejerció la jurisdicción sobre las parroquias en que había cedido las propiedades a la catedral. De hecho, su citación como merino en Alta y Retorta, un cargo compartido, quizás fuese debida a su condición de propietario en unas parroquias fuera del núcleo de su patrimonio familiar. Es razonable suponer que su actuación como merino episcopal favoreciera el crecimiento de su propio patrimonio, consolidando así las propiedades destinadas a pasar a la catedral. En este sentido, resulta significativo que en su donación casi todas las propiedades son descritas en términos tan generales que permiten su aumento sin comprometer su cesión a la catedral.

Otros casos contemporáneos en Lugo confirman que los merinos facilitaron la consolidación del patrimonio episcopal acumulando posesiones antes de cederlas a la sede. En un contrato para la institución de un merino episcopal en 1254, el matrimonio recibió una parte importante de los impuestos y cargos recaudados, comprometiéndose a dejar sus bienes al obispo despues de su muerte. ${ }^{90}$ Estas cláusulas se relacionan con las donaciones post obitum en las que los donantes retienen las propiedades donadas durante su vida así como unas propiedades pertenecientes al destinatario de la donación. ${ }^{91}$ Un documento de 1259 detalla una consolidación de heredades, recogiendo nada menos que veinte transferencias de bienes y derechos en la parroquia e iglesia de Santa Marta (Fixós) a Lupus Petri de Argonde, muy probablemente el mayordomo mayor del obispo..$^{92}$ La conservación del documento en el archivo episcopal es testimonio del destino final de las propiedades.

Aunque en su donación Rudericus Petri y Maria Pelagii no mencionan descendencia, otros textos sugieren la participación de su familia en el patrimonio y, en un caso, su sucesión en el cargo de merino. En 1235, Marina Petri donó a la catedral sus porciones de las iglesias de San

\footnotetext{
${ }^{90}$ AHN Clero 1328H/2 (27.I.1254).

${ }^{91}$ J. L. Martín, «Donaciones post obitum en los siglos XII y XIII,»El pasado histórico de Castilla y León, I Congreso de Historia de Castilla y León, Salamanca 1984, I, 235 52.

${ }^{92}$ AHN Clero 1329D/23 (11.IV.1259).
}

"CUADERNOS DE ESTUDIOS GALLEGOS", Tomo XLIII, Fascículo 108, Santiago 1996. 
Mamede de Lousada, Castelo y Constante. ${ }^{93}$ Había recibido su parte de la iglesia de Constante de su padre, Petrus Bazerii, cuyo apodo sugiere una relación con Rudericus Bazarius quien, a su vez, había retenido derechos vitalicios en Constante. En 1234, un Petrus Ruderici había vendido al obispo la mitad de la heredad de su padre, Rudericus Petri, en la parroquia de Gomelle, prometiendo no vender o empeñar la otra mitad de la heredad sino al obispo. ${ }^{94}$ El primer testigo en este documento fue Rudericus Bazarius, quizás el mismo padre del vendedor. ${ }^{95}$

Estas transacciones coincidieron con la interrupción en la actuación de Rudericus Bazarius como merino. Entre julio de 1234 y mayo de 1238, no se le cita en el cargo, aunque sí aparece en las listas de testigos. Si Petrus Ruderici y Marina Petri fueran el hijo y la nieta de Rudericus Bazarius, sus acuerdos con el obispo podrían explicar un cese temporal de Rudericus Bazarius, motivado quizás por la retención de partes del patrimonio familiar reclamado por la catedral. La escasa documentación no nos permite más que especular sobre las circunstancias concretas, pero merece notarse que la donación de Marina Petri incluye una sanción espiritual, poco común en la documentación lucense de fecha tan tardía. ${ }^{96}$ La invocación de esta sanción podría señalar el empeño del obispo de hacer cumplir las provisiones de la donación de 1220, un esfuerzo acompañado, quizás, por la destitución temporal de Rudericus Bazarius.

Rudericus Bazarius murió hacia 1246 y su mujer desapareció de la documentación al año siguiente. Documentos de fechas posteriores confirman que una parte de su patrimonio permaneció en manos de particulares y acreditan que Petrus Ruderici era, de hecho, su hijo. En 1254, Marina Iohannis vendió unas heredades en Constante que tenía de su marido de uoce Marie Pelagii, y en 1265, Pelagius Iohannis vendió al obispo una pequeña fracción de Villaris de Fargaox.${ }^{97}$ Esta había sido una

${ }^{93}$ AHN Clero 1327G/18 (3.V.1235).

${ }^{94}$ AHN Clero 1327G/8, 9 (8.IX.1234).

${ }^{95}$ Esta transacción también puede ser relacionada con una compra anterior de heredades en Gomelle por Petrus Ruderici y sus hermanos: AHN Clero 1326G/6 (8.VII.1213).

${ }^{96}$...iram dei et beate marie uirginis incurrat... Sobre la desaparición de las sanciones espirituales: L. K. Little, Benedictine Maledictions: Liturgical Cursing in Romanesque France, Ithaca 1993, 230-39; A. García y García, «Contenidos canónico-teológicos de los diplomas leoneses,» El Reino de León en la Alta Edad Media VI, León 1994, 119-28.

${ }^{97}$ AHN Clero 1087/6 (15.XI.1254), 1330D/10 (23.X.1265).

"CUADERNOS DE ESTUDIOS GALLEGOS", Tomo XLIII, Fascículo 108, Santiago 1996. 
de las propiedades concedidas al matrimonio por la duracción de su vida. Por su parte, Petrus Ruderici es titulado maiordomus, entre 1248 y 1262, en las datas de ocho transacciones en las parroquias de Trastulfe, Gomelle, Vilameá, San Martiño de Monte de Meda y San Cibrao de Monte de Meda, y en una ocasión aparece como maiordomus episcopi... de terra et de torre de Seruiam. ${ }^{98}$ Estas parroquias corresponden al núcleo de la jurisdicción de Rudericus Bazarius como merino y a la zona en la que tuvo patrimonio. Las fechas de la actuación de Petrus Ruderici sugieren que éste era su hijo, que había recibido bienes de su padre en Gomelle y le había sucedido como merino.

\section{IGLESIAS PROPIAS Y PROPIETARIOS LAICOS}

La donación y carrera de Rudericus Bazarius nos ofrece un ejemplo de la consolidación del patrimonio episcopal a través de la colaboración del obispo con los propietarios locales que le sirvieron como merinos. Un aspecto de este proceso merece más atención por la información que proporciona sobre las relaciones entre los laicos y las instituciones eclesiásticas en el desarrollo de las parroquias. Me refiero al sistema de iglesias propias, es decir, el tratamiento de las iglesias como propiedades que pueden ser vendidas, donadas, heredadas y repartidas. ${ }^{99}$

${ }^{98}$ AHN Clero 1328D/12 (5.X.1248/Trastulfe), 1086/14 (17.IV.1251/Sirvián), 1088/ 13 (23.III.1259/Gomelle), 18 (1.VIII.1259/Vilameá), 20 (1.IX.1259/San Cibrao de Monte de Meda), 1089/1 (3.II.1260/Gomelle), 5 (15.IV.1260/Gomelle, San Cibrao y San Martiño de Monte de Meda), 21 (1.III.1262/Vilameá) En 1246, dos foros concedidos por el obispo incluyeron un Petrus Ruderici maiordomus de Fonte de Agra en la lista de testigos entre los cuales estaba Rudericus Bazarius: 1328C/11, 12 (29.IV.1246). Dos documentos de 1262 citan a P. Garcie con el mismo título en relación con transacciones en las parroquias actuales de Francos y Navallos (1330A/23, 24, 25.III.1262), así que no se puede probar la identificación del maiordomo citado in 1246 con el Petrus Ruderici que actuó en la zona de Monte de Meda. En cambio, Pero Rodriguiz Travesso fue uno de los testigos de un testamento en 1258, y ésto, a mi modo de ver, establece la identificación de Petrus Travesso, citado en 1257 como merino en documentos de Vilameá, con el merino, Petrus Ruderici, de la misma zona: 1329B/19 (2.IX.1257), 1087/21 (20.XI.1257), 1088/ 1 (8.IV.1258).

${ }^{99}$ Sobre la iglesia propia en España: M. Torres López, «La doctrina de las iglesias propias en los autores españoles,» Anuario de Historia del Derecho Español II (1925), 402-61; M. Torres López, «El origen del sistema de iglesias propias,» Anuario de

"CUADERNOS DE ESTUDIOS GALLEGOS", Tomo XLIII, Fascículo 108, Santiago 1996. 
A pesar del intento de la reforma gregoriana de liberar la iglesia de los laicos, seguido por la legislación canónica de los siglos XII y XIII sobre el ius patronatus, la iglesia propia gozó de una larga vida en Galicia. ${ }^{100}$ En los siglos XII y XIII, la compraventa de iglesias fue común en toda Galicia, y los propietarios laicos abarcaban todos los sectores de la sociedad, desde las comunidades aldeanas y los pequeños propietarios hasta los caballeros y la nobleza más poderosa. Los propietarios participaban en la selección del párroco y percibían una parte de las rentas de la iglesia, bien de su dote, bien de los diezmos y otras prestaciones de los feligreses. ${ }^{101}$

Con el transcurso del tiempo, factores de diversa índole confluyeron en la transformación de este sistema. Por un lado, el impacto de los reformadores se hizo sentir en el lenguaje de las cesiones de las iglesias, los motivos de los donantes, y los mecanismos y ritmo de las transferencias. Al mismo tiempo, las iglesias propias padecieron el mismo fraccionamiento que otras heredades. Frente a esta tendencia, las institu-

Historia del Derecho Español V (1928), 83-217; R. Bidagor, La iglesia propia en España, Analecta Gregoriana IV, Roma 1933; J. Vincke, «Der Übergang vom Eigenkirchenrecht zum Patronatsrecht bezüglich der Niederkirchen in Katalonien und Aragon,» Studi Gregoriani III (1948), 451-61; J. Vincke, «Das Patronatsrecht der Aragonische Krone,» Spanische Forschungen der Gorresgesellschaft X (1955), 55-95; J. Orlandis, «Los monasterios familiares en España durante la alta edad media,» Estudios sobre instituciones monásticas medievales, Pamplona 1971, 125-64; J. Orlandis, «Los laicos y las iglesias rurales en la España de los siglos XI y XII,» Le istituzioni ecclesiastiche della 'societas christiana' dei secoli XI-XII: diocesi, pievi, e parrocchie. Atti della sesta Settimana internazionale di studio, Milano, 1-7 settembre 1974, Miscellanea del Centro di Studi medioevali VIII, Milan 1977, 261-90; Fletcher (1978), 158-75; M.I. Loring García, «Nobleza e iglesias propias en la Cantabria altomedieval,» Studia Histórica V (1987), 89-120.

${ }^{100}$ Sobre la iglesia propia en Galicia: Portela (1976), 215-19; Fletcher (1984), 224-29; M. L. Ríos Rodríguez, «Las ecclesiae dependientes de los monasterios de Jubía, Caaveiro y Monfero,» Adaxe V (1989), 105-23; M. N. Peiro Graner y M. J. Portela Silva, «El patrimonio de Osera: derechos sobre iglesias rurales (1155-1306), Actas. Congreso Internacional sobre San Bernardo e o Císter en Galicia e Portugal, Ourense 1992, I, 167-88; Pérez Rodríguez (1994), 171-82.

${ }^{101}$ Las cláusulas de la donación de la condesa $\mathrm{D}^{\mathrm{a}}$. Fronili Fernandi al monasterio de Ferreira de Pallares nos proporcionan un buen ejemplo de la especificación de algunos de estos derechos: Do adque concedo monachis...supra nominatam quartam eclesie Sancti Iacobi de Intrambasaquas cum decimacionibus adque directuris que ad diuinum sancte eclesie oficium pertinent, AHN Clero 1082/15 (10.II.1187).

"CUADERNOS DE ESTUDIOS GALLEGOS", Tomo XLIII, Fascículo 108, Santiago 1996. 
ciones eclesiásticas y, en cierta medida, las grandes casas señoriales resistieron mejor que los pequeños propietarios. Al consolidar porciones de iglesias, los grandes propietarios disminuyeron el valor de las minúsculas fracciones que quedaron en manos de los pequeños propietarios.

En Lugo, los titubeantes intentos de reforma se concentraron en el último tercio del siglo XII y el primer tercio del siglo XIII, una época que coincidió con la reforma capitular y el gran auge de los cistercienses y las órdenes militares que estimularon las donaciones de los fieles. ${ }^{102}$ En estos años aumentaron las donaciones de iglesias a la sede, mientras que las compraventas de iglesias disminuyeron notablemente. ${ }^{103}$ Los arrendamientos de iglesias a los laicos se mantuvieron, pero sus cláusulas reflejaron el interés creciente por el mantenimiento del culto. ${ }^{104} \mathrm{Las}$ donaciones procedieron de todos los sectores sociales, destacando las concesiones de porciones de múltiples iglesias por personajes importantes, a veces acompañadas de otras manifestaciones de religiosidad como la peregrinación. ${ }^{105}$ En algunas cartas, el lenguaje indica la conciencia de la condena de la posesión de iglesias por los laicos, o, al menos, distingue el trato de bienes seglares de los eclesiásticos. ${ }^{106}$ En este

${ }^{102}$ Estas conclusiones forman parte de un estudio en preparación sobre la iglesia propia en la diócesis de Lugo. Un avance fue presentado en el 24th Annual Meeting of the Society for Spanish and Portuguese Historical Studies, San Antonio, 1993, «The Proprietary Church in the Diocese of Lugo, 1130-1270,». El resumen fue publicado en Bulletin of the Society for Spanish and Portuguese Historical Studies XVIII no. 2 (1993), 21.

${ }^{103}$ Entre 1192 y 1229 , por ejemplo, los documentos de la catedral contienen solo una compraventa de una iglesia entre particulares: AHN Clero 1326F/23 (1212).

${ }^{104}$ Como en el caso de $\mathrm{D}^{\mathrm{a}}$. Urraca Adefonsi que se compremetió a construir la iglesia: AHN Clero 1325G/13 (30.IX.1182), publicado por Fletcher (1978), 251-52

${ }^{105}$ Importantes ejemplos de la donación de múltiples iglesias incluyen: AHN Clero 1327B/10 (15.V.1222), 11 (18.V.1222). Para una donación concedida antes de una peregrinación: 1326E/19, 20 (20.IV.1210), publicada por J.I. Fernández de Viana y Vieites, «Documentos sobre peregrinos gallegos a Jerusalén en la Edad Media,»Estudios Mindonienses VII (1991), 418.

${ }^{106}$ Ejemplos de cláusulas que mencionan o aluden al pecado de poseer iglesias incluyen: AHN Clero 1325H/12 (26.I.1190), 16 (16.V.1191), 1326B/3 (13.VI.1197), 1326F/12 (22.II.1212). Para transacciones que separan la venta de heredades laicas de la donación de iglesias: 1327G/10 (21.XI.1234), 13 (25.XII.1234). Transacciones similares aparecen en la documentación monástica: 1328A/6 (VII.1240/Monfero); M. R. Romaní Martínez, Colección diplomática do mosteiro cisterciense de Sta. María de Oseira (Ourense) 1025-1310, I, doc. 324 (VIII.1230), pp. 315-16. En otros casos, la venta de propiedades laicas y la donación de iglesias fueron tratadas en documentos separados: 1327D/19 (24.II.1230), 21 (28.II.1230).

"CUADERNOS DE ESTUDIOS GALLEGOS", Tomo XLIII, Fascículo 108, Santiago 1996. 
sentido, la lenta difusión del concepto canónico del ius patronatus a partir del primer cuarto del siglo XIII ofrece otra señal de la recepción de las ideas de los reformadores. ${ }^{107}$

A mediados del siglo XIII, la reforma había perdido gran parte de su impulso. Las compraventas de iglesias resurgieron con la participación del clero y las instituciones eclesiásticas, y el nuevo concepto del ius patronatus fue asimilado al viejo sistema de iglesias propias. ${ }^{108} \mathrm{El}$ obispo dirigió sus intentos de recuperación de iglesias a la consolidación del patrimonio, tanto laico como eclesiástico, de la catedral. Este motivo explica, por ejemplo, la larga serie de adquisiciones de pequeñas porciones de las iglesias de Mazoi y Muris (Burgo) en los años en que el obispo construyó palacios y granjas en estas parroquias. ${ }^{109}$

En este contexto, no es sorprendente que la mayoría de las iglesias del distrito de nuestro estudio estuvieran, al menos en parte, en manos de laicos en el siglo XIII, a pesar de estar dentro del coto lucense. Sin embargo, no es fácil identificar sus propietarios dado que los documentos dicen poco de los laicos que retuvieron sus porciones de iglesias. La misma naturaleza de las fuentes deforma la realidad histórica ya que su procedencia eclesiástica hace que los propietarios laicos generalmente aparezcan solo en el momento en que ceden su propiedad eclesiástica.

Los documentos más llamativos son aquellos en los que un solo propietario dona sus porciones de varias iglesias. Las iglesias de la zona de

\footnotetext{
${ }^{107}$ En la documentación de la catedral de Lugo, los primeros ejemplos del uso de este término son documentos de clérigos o caballeros destacados: AHN Clero 1326E/19, 20 (20.IV.1210), 1327A/13 (2.VIII.1219), 1327B/3 (1.XII.1221). A partir de 1239, las referencias al ius patronatus son más frecuentes. Sobre el ius patronatus: P. Landau, Ius Patronatus. Studien zur Entwicklung des Patronats im Dekretalenrecht und der Kanonistik des 12. und 13. Jahrhunderts, Colonia, 1975.

${ }^{108}$ Buenos ejemplos de la equivalencia de los dos conceptos son las dos copias del testamento de $\mathrm{D}^{\mathrm{a}}$. Taresia Fernández de Mirapeixe, AHN Clero 1328F/6 (29.IX.1251), 7 (30.IX.1251); y dos compras de propiedad en la iglesia de San Mamede de Lousada, 1330A/10 (2.VIII.1261), 26 (30.III.1262).

${ }^{109}$ Para la construcción de las casas del obispo en Mazoi: AHN Clero 1328C/19 (16.IX.1246), 1328D/26 (17.VIII.1249), 1328E/11 (24.VIII.1250). Para el palacio episcopal en Muris (Burgo): 1329B/3 (21.I.1257). La larga serie de adquisiciones en la iglesia de Muris empieza en 1220 con la citada donación de Rudericus Petri Bazarius. Entre 1248 y 1267, se pueden citar quince donaciones o ventas de porciones de la iglesia de Mazoi al obispo.
}

"CUADERNOS DE ESTUDIOS GALLEGOS", Tomo XLIII, Fascículo 108, Santiago 1996. 
Monte de Meda se incluyeron en varias donaciones de este tipo. La citada donación de Rudericus Bazarius y Maria Pelagii comprendió porciones o derechos en las iglesias de San Miguel de Constante, Calde, Muris (Burgo), Sta. Cruz de Retorta, San Martiño de Monte de Meda, Alta, Orbazai, Campo y Piñeiras. ${ }^{110}$ En 1230, Da . Peironela donó a la catedral sus posesiones en las iglesias de Calde, Muris (Burgo), Sta. Cruz de Retorta y Orbazai. ${ }^{111}$ La catedral de Lugo no fue la única beneficiaria de este tipo de donaciones. En 1233, el matrimonio de Iohannes Ruderici y Maria Ruderici, donó al monasterio de Ferreira de Pallares, entre otros bienes, sus derechos en diecinueve iglesias que incluyeron las tres iglesias de Monte de Meda y la de San Miguel de Constante. ${ }^{12}$ En 1259, el monasterio recibió en donación post obitum de Joam Pérez, clérigo de Soñar, los iglesarios de Vilameá, San Martiño de Monte de Meda, Mosteiro de Castelo, San Xurxo y San Miguel de Constante, todos heredados de su padre, Pedro Fernández de Gomelle. ${ }^{113}$

En estas donaciones no se especifican las porciones de las iglesias cedidas, pero la repetición de las mismas iglesias en varias donaciones sugiere que algunas de éstas experimentaron un fraccionamiento intenso. Tres de las donaciones citadas incluyen porciones de San Miguel de Constante y San Martiño de Monte de Meda. La iglesia de Constante entró también en la donación de Marina Petri a Lugo en 1235, ambas iglesias figuran en una donación de porciones de doce iglesias a Lopo Rodríguez de Rodeiro en 1263, y una porción de San Martiño de Monte de Meda fue excluída de una venta a Ferreira de Pallares en 1233. ${ }^{114}$ Hacia 1260, tres documentos distintos se refieren a la repartición de las porciones de Nuño

\footnotetext{
${ }^{110}$ Cit. n. 86.

111 AHN Clero 1327D/14 (22.I.1230).

112 AHN Clero 1084/14, 15 (6.XII.1233).

${ }^{113}$ AHN Clero 1088/11 (15.II.1259), publicado en A. Martínez Salazar, Documentos Gallegos de los siglos XIII al XVI, La Coruña 1911, 27.

${ }^{114}$ AHN Clero 1327G/18 (3.V.1235), 1090/4 (10.XI.1263), 1084/12 (25.IX.1233). La ambigüedad de otras ventas de propiedades en estas parroquias nos impide saber si se trataron de porciones de las iglesias. Este es el caso de la gran donación a la catedral hecha por Urraca Petri, hija del canónigo, Petrus Adefonsi de Meilán, de propiedades en siete parroquias incluyendo la de San Martiño de Monte de Meda, 1327A/20 (27.V.1220) y de una donación a Ferreira de Pallares de propiedades en Zolle, Constante y San Xurxo, 1086/21 (22.VI.1254).
}

"CUADERNOS DE ESTUdIOS GALLEGOS", Tomo XLIII, Fascículo 108, Santiago 1996. 
Vermuiz en las iglesias de Gomelle, Muris (Burgo), San Martiño de Monte de Meda y San Cibrao de Monte de Meda entre el monasterio de Ferreira, la catedral de Lugo y varios particulares. ${ }^{115}$

Una modesta venta particular subraya el grado de fraccionamiento sufrido por estas iglesias. En 1260, dos matrimonios pagaron dieciséis sueldos por una heredad compuesta de bienes laicos y eclesiásticos en las parroquias de Castelo, Constante y San Martiño de Monte de Meda. ${ }^{116}$ Aunque no se especifican las porciones de las iglesias, su bajo precio es comparable a los veinte sueldos pagados por el obispo en 1267 por una porción, equivalente a $1 / 112$, del ius patronatus de otra iglesia del coto, Sta. Eulalia de Mazoi. ${ }^{117}$ En la misma zona de Constante, la complicada repartición de heredades laicas ilustra el proceso análogo que afectó a las iglesias propias. En 1253, Petrus Nuniz vendió su heredad en el casal de Constante a ocho individuos o familias, repartiéndola entre los compradores en porciones desiguales. ${ }^{118}$ El precio total de diez sueldos ya implica una porción mínima del casal, y, de ésta, las fracciones citadas incluyen una vigésima.

Más corriente que la repartición entre múltiples compradores fue la división entre herederos. Aunque no documentado directamente, este proceso quedó reflejado en las descripciones de propiedades en transacciones que, paradójicamente, tenían como objetivo la consolidación de posesiones. ${ }^{119}$ En 1242, por ejemplo, el sacerdote, Iohannes Suarii, adquirió bienes en la parroquia de Entrambasaugas en seis compras distintas. Los bajos precios y la mención de una quinceava de una heredad atestiguan la intensa fragmentación de estas propiedades. ${ }^{120}$ En la parroquia de Vilameá, los hijos de Sancia Ueremudi hicieron una

\footnotetext{
115 AHN Clero 1085/1bis (22.VI.1259), 1089/5 (15.IV.1260), 1329G/17 (25.VIII.1260).

${ }^{116}$ AHN Clero 1089/4 (23.III.1260).

117 AHN Clero 1330E/21 (21.V.1267).

118 AHN Clero 1086/19 (21.XI.1253).

${ }^{119}$ Un caso de la repartición de una iglesia a través de una donación es el de la donación per quartas a cuatro hermanos por Lupus Ruderici de Rodeiro miles y su mujer, $D^{a}$. Urraca Iohannis, de la parte que tenía D. Fernandus Ruderici de Cortes en la iglesia de San Cibrao de Monte de Meda, AHN Clero 1090/11 (10.II.1265); para otro ejemplo de la repartición de una heredad laica entre varios compradores, 1087/6 (15.XI.1254).

${ }^{120}$ AHN Clero 1327H/6 (I.1242).
}

"CUADERNOS DE ESTUDIOS GALLEGOS", Tomo XLIII, Fascículo 108, Santiago 1996. 
serie de compras de porciones de la iglesia y propiedades laicas que incluyeron una décimosexta parte de un casal. ${ }^{121}$

Uno de los mejores ejemplos de la fragmentación y reconstitución de las porciones de una iglesia propia procede de un distrito vecino donde Lupus Petri de Argonde adquirió bienes en la iglesia y parroquia de Santa Marta (Fixós) a través de veinte transacciones registradas en un espléndido pergamino. ${ }^{122} \mathrm{El}$ precio total de 1.623 sueldos, que no incluye el valor de los bienes que le fueron donados, indica el alto grado de consolidación de las propiedades. Al mismo tiempo, las transacciones individuales detallan el extremado fraccionamiento de la iglesia a través de generaciones, describiendo porciones como una cuarta de la mitad de tres quintas de una octava de una tercia o una octava de una octava de una cuarta de una tercia. Este singular documento nos muestra el proceso de consolidación que, con toda probabilidad, dio lugar a las posiblemente grandes porciones de iglesias incluidas en las amplias donaciones del merino Rudericus Bazarius o del clérigo Joam Pérez de Soñar. Es así como merinos y clérigos facilitaron la lenta recuperación de iglesias y la concentración de porciones de iglesias en manos de las instituciones eclesiásticas.

De este proceso de concentración dan fe los archivos de la catedral de Lugo y el monasterio de Ferreira de Pallares. De las catorce parroquias actuales que conforman el distrito de nuestro estudio, consta que la catedral de Lugo adquirió porciones de las de Calde, Castelo, Constante, Gomelle, San Martiño de Monte de Meda y Vilameá en el siglo XIII. ${ }^{123}$ Otros documentos refieren a sus posesiones en la iglesia de Sirvián y la de Trastulfe, hoy desaparecida. ${ }^{124}$ Se puede inferir su posesión de la iglesia

\footnotetext{
${ }^{121}$ AHN Clero 1088/18 (1.VIII.1259).

${ }^{122}$ AHN Clero 1329D/23 (11.IV.1259).

${ }^{123}$ A las ya citadas transacciones, se puede añadir la venta al obispo de una heredad in ecclesia et tota filigrigia de Sancto Martino de Villa Meaa, AHN Clero 1329B/19 (2.IX.1257), y una donación a los canónigos de unas heredades in ecclesia et filigregia Sancti Christophori de Gomeelle en 1279: AHN Cód. 1042B, f. 4v, publicado por S. Jiménez Gómez, «O Memorial de Aniversarios da Catedral de Lugo como fonte para o estudio da sociedade medieval,» Jubilatio. Homenaje de la Facultad de Geografía e Historia a los Profesores D. Manuel Lucas Alvarez y D. Angel Rodríguez González, Santiago 1987, I, 216.

${ }^{124}$ Sirvián: AHN Clero 1328H/3 (30.I.1254); Trastulfe: AHN Clero 1327A/26, 27 (27.III.1221).
}

"CUADERNOS DE ESTUDIOS GALLEGOS", Tomo XLIII, Fascículo 108, Santiago 1996. 
de Lamas por su citación —única en la época- entre las posesiones de Santuiño de Fingoi cuando Alfonso VI donó la mitad de este cenobio a la catedral en 1088. ${ }^{125}$ Por lo que se refiere a Pradeda y Entrambasaugas, incluidas en el privilegio atribuido a Alfonso III, no hemos encontrado evidencia firme de que la catedral retuviera porciones de estas iglesias. ${ }^{126}$ Por otra parte, hay amplios testimonios de que tanto particulares como el monasterio de Ferreira tenían porciones importantes de ambas iglesias en el siglo XIII, y, de hecho, el monasterio fue el principal rival de la catedral en la posesión de las iglesias del distrito.

Un cuaderno donde se recogen las adquisiciones de Ferreira de Pallares nos ayuda a determinar el patrimonio eclesiástico del monasterio hacia finales del siglo XIII. ${ }^{127}$ En este distrito, éstas incluyeron porciones de las iglesias de Pradeda, Entrambasaugas, Constante, Gomelle, Vilameá y las tres iglesias de Monte de Meda. Según esta recopilación, el monasterio poseía la mitad de la iglesia de Entrambasaugas, una cuarta donada por la condesa $D^{a}$. Fronili Fernandi y otra cuarta por D. Pedro Moniz Corna, ambos miembros de la familia de los fundadores del monasterio. De la iglesia de Constante y las tres iglesias de Monte de Meda, tenía las porciones de $\mathrm{D}^{\mathrm{a}}$. Loba que incluyeron una cuadragésima parte de la iglesia de Sta. Madanela, una décimosexta parte de San Martiño, y la décima parte de San Cibrao. El monasterio recibió unas porciones de las iglesias de Gomelle y Vilameá de varios particulares y en la complicada repartición de la iglesia de Pradeda, ganó una mitad y al menos cuatro novenas partes de la otra mitad.

Otros documentos completan las noticias del cuaderno. En 1241, una serie de adquisiciones en la iglesia de Pradeda incluyó un acuerdo con los herederos de Rudericus Ruderici sobre la división a medias de su mitad de la iglesia y dos donaciones de unas porciones de la parte que pertenecía a Fernandus Veremudi. ${ }^{128}$ En 1263, el monasterio permutó una heredad en

125 AHN Cód. 1043B, f. 13v (21.VII.1088), cf. M.R. García Alvarez, «Los monasterios lucenses de Santalla y Santuiño de Fingoy,» Yermo V (1967), 64-66, 68-69.

126 En 1094, Suarius Munionis donó la duodécima parte de Santiago de Entrambasaugas a la catedral, sin especificar si se trataba de la iglesia, cit. n. 28. Quizás la especificación de heredades laicas o eclesiásticas, común en la documentación local de los siglos XII y XIII, fue otra señal de la recepción de las ideas de los reformadores.

${ }^{127}$ AHN Clero 1096/12. El cuaderno se titula, Renembrança dos herdamentos de Ferraria e de quen los gaano.

${ }^{128}$ AHN Clero 1085/7 (V.1241), 8 (19.VI.1241), 11 (IX.1241).

"CUADERNOS DE ESTUDIOS GALLEGOS", Tomo XLIII, Fascículo 108, Santiago 1996. 
la parroquia por otro quiñón de la iglesia. ${ }^{129}$ De la gran donación de Iohannes Ruderici y Maria Ruderici, el cuaderno se ciñe a citar unas propiedades laicas, pero, al confirmar que Maria Ruderici fue la hija de doña Loba, abre la posibilidad de que la donación del matrimonio hubiera sido, en parte, la restauración de los bienes ya donados por doña Loba y citados como tal en el cuaderno. ${ }^{130}$ La donación de Joam Pérez clérigo de Soñar en 1259 incluyó porciones de dos iglesias —Castelo y San Xurxoomitidas del cuaderno. ${ }^{131}$ En el mismo año, Rodrigo Nuniz prelado de Lavalos (Navallos) se comprometió a ceder su porción de la iglesia de Gomelle al monasterio a su muerte, recibiendo a cambio una tenencia vitalicia sobre la parte de la iglesia de San Martiño de Monte de Meda que el monasterio había ganado de su abuelo, Nunus Virmuiz. ${ }^{132}$

En total, en el último tercio del siglo XIII, el monasterio disfrutaba de porciones de las iglesias de nueve de las catorce parroquias actuales de este distrito, más unas porciones de la iglesia desaparecida de San Xurxo de Constante. Su posesión de porciones importantes de iglesias y bienes en el coto de Lugo, a veces compartida con la catedral, ocasionó conflictos con los clérigos de estas parroquias sobre las prestaciones debidas al monasterio. El convento se quejó a Roma y, en 1263, el Papa Urbano IV encargó al obispo de Ourense que investigara las reclamaciones del abad contra los rectores y clérigos de Soñar, Roveredo (Reboredo), Tramonte (Sta. Madanela de Monte de Meda), San Martiño de Monte de Meda, Gomelle y San Miguel de Constante. ${ }^{133}$

El auge del monasterio de Ferreira se debió, en parte, al creciente poder de los Rodeiro, cuyo representante más ilustre, D. Munio Fernández, sirvió a Fernando III como merino mayor en Galicia, participó en la reconquista de Sevilla, y actuó, con su hermano D. Rodrigo Fernández, como patrón y protector del monasterio que eligió como lugar de

${ }^{129}$ AHN Clero 1090/5 (12.XI.1263).

${ }^{130}$ AHN Clero 1084/14, 15 (6.XII.1233).

131 cit. n. 112.

${ }^{132}$ AHN Clero 1085/1bis (22.VI.1259).

${ }^{133}$ AHN Clero 1090/1 (10.I.1263). El documento no está incluido entre los recogidos en I. Rodríguez R. de Lama, La documentación pontifícia de Urbano IV (1261-1264), Roma 1981.

"CUADERNOS DE ESTUDIOS GALLEGOS", Tomo XLIII, Fascículo 108, Santiago 1996. 
sepultura. ${ }^{134}$ Los Rodeiro descendieron del amplio linaje de los fundadores del monasterio, cuyos miembros, como ya vimos, tenían amplias propiedades en este distrito en los siglos XI y XII y donaron bienes importantes al monasterio de Ferreira y la catedral de Lugo.

En la primera mitad del siglo XIII, el poder de la familia dentro del coto de Lugo ya se había desvanecido, según se vislumbra en unas referencias escuetas. En 1221, el obispo D. Ordonius llegó a un acuerdo con $\mathrm{D}^{\mathrm{a}}$. Eldoncia Martini, concediéndole de por vida la iglesia de Trastulfe, una heredad con serviciales en la pequeña parroquia y otras dos en la parroquia de San Cibrao de Monte de Meda. ${ }^{135}$ A cambio, ella renunció a sus reclamaciones sobre iglesias, heredades y otras posesiones que la catedral ganara de sus antepasados, el conde D. Munio Pelagii y la condesa $\mathrm{D}^{\mathrm{a}}$. Lupa. En 1241, la catedral recibió otros bienes de la familia en la parroquia de Sirvián a través de una compra del monasterio de Ferreira de propiedades que fueron posesión de D. Fernando Munionis, hijo del mencionado conde. ${ }^{136}$

D. Munio Fernández de Rodeiro frenó la fragmentación y dispersión del patrimonio familiar. Con su hermano, D. Rodrigo Fernández, logró reunir un gran patrimonio, concentrado en la diócesis de Lugo, e incorporando porciones de numerosas iglesias. En el distrito de Monte de Meda, D. Munio Fernández y su segunda mujer, Da. . Maior Alfonsi, recibieron una porción de la iglesia de Castelo en 1255, e invirtieron la notable cantidad de 730 sueldos en la compra de una heredad en Villar de Infanzoes en la parroquia vecina de Pradeda en $1257 .{ }^{137}$ Los dos hermanos murieron hacia 1262, pero el hijo de D. Rodrigo Fernández, Lopo Rodríguez, asumió el papel de patrón del monasterio de Ferreira. En 1263, un particular le cedió sus porciones de doce iglesias que incluyeron San

${ }^{134}$ Como resultado de su patronato, buen número de documentos que protagonizaron estos caballeros pasaron al archivo del monasterio y se encuentran actualmente entre los fondos de los monasterios de Ferreira de Pallares y Samos en la sección de Clero del AHN.

${ }^{135}$ AHN Clero 1327A/26, 27 (27.III.1221).

${ }^{136}$ AHN Clero 1328A/18 (20.VII.1241). No es el D. Fernandus Munionis citado en n. 57.

${ }^{137}$ AHN Clero 1087/8 (15.VII.1255), publicado en C. de Azevedo Maia, História do Galego-Portugues. Estado linguístico da Galiza e do Noroeste de Portugal desde o século XIII ao século XVI, Coimbra 1986, doc. 19, p. 68; 1087/15 (27.V.1257).

"CUADERNOS DE ESTUDIOS GALLEGOS", Tomo XLIII, Fascículo 108, Santiago 1996. 
Miguel de Constante y las tres de Monte de Meda, y en 1265, él donó a cuatro hermanos todo el ius patronatus y la parte que tenía D. Fernandus Ruderici de Cortes en la iglesia de San Cibrao de Monte de Meda. ${ }^{138}$

Del análisis de la documentación con que contamos, se puede concluir que, en el último tercio del siglo XIII, la catedral tenía porciones de nueve iglesias del distrito de Monte de Meda, el monasterio de Ferreira poseía quiñones de diez, y los Rodeiro tenían porciones de al menos cinco. La procedencia de las fuentes podría exagerar el predominio de estos grandes propietarios. Por lo tanto, es importante señalar la pervivencia de pequeños propietarios, confirmada por una venta particular de quiñones de hasta seis iglesias del distrito en 1273:

Ego Johannes Petri, pro Martino Pelagii, pro Marina Pelagii, pro Maiore Pelagii, pro Fernando Pelagii, pro Jacobo Pelagii fratribus, vobis Petro Fernandi, Johanni Petri et uxori uestre, Maiori Guiliellmi, Petro Ruderici et uxori uestre, Johaninne Petri, per tercias, libenti animo, vendo sextam partem tocius hereditatis eccliastice et laycalis quam Petrus Pelagii et uxor eius Azenda Petri habebant et habere debebant sub aula Sancti Michaelis de Costante et Sancti Jeorgii et Sancti Vireximi de Bazar et Sancti Saluatoris de Calde et Sancti Saluatoris de Castelo et Sancte Eolalie de Pradeada, cum totis pertinenciis et directuris suis... accipio a uobis pro ea L solidos... ${ }^{139}$

Al mismo tiempo, la intensa repartición de las porciones de los pequeños propietarios, evidenciada en este caso, debe haber dificultado el ejercicio de sus derechos frente a los grandes propietarios que acumularon porciones de las mismas iglesias.

Es más fácil identificar las iglesias repartidas entre estas instituciones que precisar las porciones que éstas poseían en cada iglesia. A menudo, dos o tres grandes propietarios tenían quiñones en las mismas iglesias. Así, la catedral de Lugo, el monasterio de Ferreira y los Rodeiro compartieron las porciones de las iglesias de San Martiño de Monte de Meda, Constante y Castelo, al lado de los pequeños propietarios que

\footnotetext{
${ }^{138}$ AHN Clero 1090/4 (10.XI.1263), 11 (10.II.1265).

${ }^{139}$ AHN Clero 1092/4 (25.XII.1273).
}

"CUADERNOS DE ESTUDIOS GALLEGOS", Tomo XLIII, Fascículo 108, Santiago 1996. 
retuvieron porciones de las tres iglesias. El monasterio de Ferreira compartió la posesión de las iglesias de Gomelle y Vilameá con la catedral y la de las iglesias de Sta. Madanela y San Cibrao de Monte de Meda con los Rodeiro. En éstas también, las pequeñas porciones obtenidas y el número de estas adquisiciones insinúan la pervivencia de los pequeños propietarios.

\section{EL CLERO PARROQUIAL}

Uno de los derechos más importantes de los propietarios de iglesias era la presentación de los clérigos. En el siglo XIII, el clero parroquial adquiere un mayor protagonismo. Ellos mismos aparecen como propietarios de iglesias y participando en la resolución de pleitos y la aseguración de acuerdos. Algunos de ellos nos han dejado sus testamentos, pero las fuentes más numerosas son, como en el caso de los merinos, las escuetas referencias en las datas o listas de testigos. En estas listas, la proporción de clérigos relacionados con iglesias parroquiales aumenta con el avance del siglo XIII. El análisis de estos datos requiere una cuidadosa consideración de la terminología aplicada al clero por los distintos escribas y notarios. Así se pueden establecer los criterios usados para diferenciar los sacerdotes de otros clérigos e identificar aquellos sacerdotes que rigieron las parroquias.

En el coto de Lugo y sus alrededores, los términos más comunes para referirse a los clérigos son: clericus/clerigo, presbyter y prelatus/ prelado. ${ }^{140}$ Este último es el título que designa con mayor exactitud el oficio de párroco, pero su uso varía según el escriba. Fernandus Pelagii, el notario de Lugo, apenas lo usó, pero los notarios de otros distritos de la diócesis lo emplearon frecuentemente y, a veces, nombraron los prelados

${ }^{140}$ Un capellanus fue citado en la parroquia de Sirvián: AHN Clero 1327B/7 (30.III.1222). El término rector, fue de uso común en la diócesis de Ourense y la parte meridional de la diócesis de Lugo donde los ejemplos incluyen Sancius Munionis, titulado prelati Sancti Stephani de Atán, 1327C/12 (21.I.1228) y rector ecclesie Sancti Stephani de Atan, 1327F/26 (29.IV.1234). Otros términos empleados con menos frecuencia fueron sacerdos y monacus

"CUADERNOS DE ESTUDIOS GALLEGOS", Tomo XLIII, Fascículo 108, Santiago 1996. 
en las datas. ${ }^{141}$ Esto explica por qué tres de los cuatro clérigos titulados prelatus/prelado en el distrito de nuestro estudio rigieron parroquias fuera del coto lucense: Rodrigo Ovequez, prelado de Castelo y P. Cayde y P. Pelagit, ambos prelados de Pradeda. ${ }^{142}$ La documentación confirma que muchos prelados fueron sacerdotes, pero no podemos afirmar que éste haya sido el caso de los dos prelados de Pradeda. P. Cayde es citado como prelado en una única referencia en 1265. Por su parte, P. Pelagit, relacionado con Pradeda en cinco documentos distintos entre 1257 y 1260, fue tituladoprelatus una vez y clericus/clerigo cuatro veces. ${ }^{143}$ Esto no excluye la posibilidad de que P. Pelagit haya sido sacerdote, pero algunos notarios reservaron el término clericus/clerigo para quienes no habían recibido las órdenes sacerdotales.

Fernandus Pelagii de Lugo empleó estos términos con cierta precisión, distinguiendo entre clérigos y sacerdotes en un mismo documento, o repitiendo el mismo título para un individuo determinado en una serie de documentos. Los casos que apuntan con más claridad a una distinción consciente son los referidos a los clérigos que se elevaron al sacerdocio, como Petrus Talan de Lugo, titulado clericus a partir de 1248, y presbyter a partir de $1260 .{ }^{144}$ Petrus Talan empezó su carrera en el coro de Lugo y atestiguó una cincuentena de documentos, casi todos redactados por Fernandus Pelagii, lo que explica la regularidad de su titulación. ${ }^{145}$ Aún

${ }^{141}$ Entre los notarios que emplean los términos prelatus/prelado a mediados del siglo XIII, están Ioham de Santiago, notario de Portomarín; Dominicus Iohannis, notario de Sarria; Michael Fernandi, notario de Páramo y Gondrame; Petrus Garsie, notario de Monforte de Lemos; y Alfonsus Roderici, un escriba que actuó en la zona de Portomarín.

142 Rodrigo Ovequez prelado de moesterio de Castelo: AHN Clero 1091/12 (10.V.1271); P. Pelagit prelatus ecclesie Sancte Eolalie, 1089/9 (23.V.1260), P. Cayde prelati Sancte Eolalie 1090/10 (27.I.1265); Ioam Rodriguez, prelado da eglesa de Sanctiago duntranbasaquas (Entrambasaugas), fue protagonista de un foro: 1244/11 (20.IX.1269), publicado por M. Sponer, «Documentos antiguos de Galicia,» Anuari de l'oficina romanica de lingüística i literatura VII (1934), doc. 30, p. 151.

${ }^{143}$ Clericus: AHN Clero 1087/17 (21.IX.1257); Clerigus: 1088/8 (22.IX.1258), publicado en Azevedo (1986), doc. 23, pp. 72-73; Clerigo: 1085/1bis (22.VI.1259), 1089/3 (16.III.1260).

${ }^{144}$ Aparece por primera vez como clericus de coro: AHN Cód. 1041B, f. 23 bis r. (23.V.1248), publicado en Jímenez Gómez (1987), 201. Fue titulado presbyter a partir de 1329F/24 (11.V.1260).

${ }^{145}$ Estos documentos están en AHN Clero 1328F, G, H, '1329A, B, C, D, E, F, G, 1330C, D, G.

"CUADERNOS DE ESTUDIOS GALLEGOS", Tomo XLIII, Fáscículo 108, Santiago 1996. 
así merece tenerse en cuenta que Fernandus Pelagii volvió a llamarle clérigo unas semanas después de su primera citación como sacerdote. ${ }^{146}$ Más aún, en varios documentos, es citado sin título, pero su singular apellido y el contexto de los documentos nos garantizan que se trata de la misma persona. ${ }^{147}$ Este ejemplo llama a la precaución en la lectura de estos títulos, ya que incluso el lenguaje de notarios tan expertos y precisos como Fernandus Pelagii admite variaciones aleatorias.

Si el citado ejemplo sugiere una distinción entre los términos clericus y presbyter, no faltan escribas que aplicaron el término general de clericus a los sacerdotes, designando a las mismas personas presbyter y clericus en un mismo texto o en una serie de documentos. ${ }^{148}$ Estas variaciones cobran importancia en los documentos de notarios como Fernandus Pelagii que normalmente respetan esta distinción. Entre 1257 y 1269, Fernandus Pelagii citó a Petrus Petri de Saa cinco veces como Petrus Petri clericus de Saa, y dos veces como Petrus Petri de Saa presbyter. ${ }^{149}$ Con toda probabilidad, éste es el mismo Petrus Petri presbyter que atestiguó transacciones en la pequeña parroquia adyacente de Sta. Marta (Fixós) en 1250,1261 y $1266^{150}$. La lista de testigos de un documento de 1268 puede explicar esta insólita variación ya que el nombre del clérigo precede al de su hijo, Fernandus Petri. ${ }^{151}$ Cabe pues pensar que la variación del título surgió de la ambígua condición de un sacerdote que había roto su celibato.

Estas consideraciones sobre la terminología nos pueden ayudar en la investigación del clérigo más documentado del distrito de Monte de

\footnotetext{
146 AHN Clero 1329G/4 (28.V.1260).

${ }^{147}$ Entre varios ejemplos: AHN Clero 1328H/7 (27.IV.1254), 1329A/17 (1.IX.1256), 1330C/2 (27.VI.1263).

${ }^{148}$ Tres personas tienen el título de clericus y de presbyter en el mismo documento, AHN Clero 1086/15 (8.IX.1251); Entre los ejemplos de presbyteri que vuelven a ser llamados clerici están D. Duran de Nespereira, 1328A/2 (20.III.1240), 1087/1 (VIII/ IX.1254); Garsias Petri de Nigral, 1328G/17 (10.X.1253), 1089/8 (3.V.1260); Iohannes Iohannis de Pinza, 1329B/7 (12.III.1257), 1330E/24 (3.VI.1267); y Iohannes Petri de Saamasas, 1327C/7 (5.III.1227), 1327D/14 (22.I.1230).

149 Clericus, AHN Clero 1329B/20 (17.XI.1257), 1329D/7 (15.X.1258), 23 (11.IV.1259), 1330F/16 (13.VII.1268), 1330G/5 (15.III.1269). Presbyter, 1329D/4 (23.IX.1258), 1330D/12 (27.XII.1265).

${ }_{150}$ AHN Clero 1328E/7 (13.VII.1250), 1329H/17 (9.II.1261), 1330D/22 (2.IX.1266).

${ }^{151}$ AHN Clero 1330F/16 (13.VII.1268).
}

"CUADERNOS DE ESTUDIOS GALLEGOS", Tomo XLIII, Fascículo 108, Santiago 1996. 
Meda, Fernandus Nuni de San Cibrao. En 1254, Fernandus Nuni atestiguó dos documentos como clérigo de San Cibrao (Monte de Meda). ${ }^{152}$ De hecho, podría ser el mismo Fernandus Nuniz clericus que siguió al clérigo de Lamela entre los testigos de un foro de Vilameá en 1244. ${ }^{153}$ En 1257, los hijos que el clérigo Fernandus Nuniz había tenido con Sancia Veremudi compraron una parte de un casal en Vilameá. ${ }^{154} \mathrm{El}$ hecho de que éstos aparezcan citados como hijos de Sancha Veremudi en varias transacciones insinúa la ilegitimidad de su condición. ${ }^{155}$ Que este Fernandus Nuniz fue el mismo clérigo de San Cibrao lo confirma el testamento de 1258 en que Fernam Nunez de San Cibrao legó propiedades a sus hijos e hizo provisiones paraSancha Uermuez. ${ }^{156}$ Pese a la grave enfermedad que motivó la preparación del testamento, Fernandus Nuniz vivió al menos un año más. El abad de Ferreira lo nombró juez en un pleito sobre una heredad en Nespereira, y dom Fernando Nuniz de San Cibrao atestiguó la donación de Joam Perez, clérigo de Soñar, al monasterio. ${ }^{157}$

Fernandus Nuniz es el único clérigo del distrito del que poseemos su testamento. La elección de Ferreira de Pallares como lugar de sepultura, acompañada de mandas generosas, subraya una vinculación con el monasterio que, como ya vimos, era uno de los propietarios de la iglesia de San Cibrao. Esta iglesia también fue beneficiaria del testamento, que mandó la terminación de un breviario y la elaboración de un cáliz de un marco de plata para la misma. Al arcipreste, no identificado, Fernandus Nuniz dejó la mitad de su ropa, una manda que podría indicar el fortalecimiento de la organización jerárquica del clero local bajo la jurisdicción del arcipreste. ${ }^{158}$ Los legados a las instituciones religiosas o

${ }^{152}$ AHN Clero 1086/21 (22.IV.1254), 1087/1 (VIII/IX.1254).

${ }^{153}$ AHN Clero 1085/16 (2.I.1244).

154 AHN Clero 1087/21 (20.XI.1257).

${ }^{155}$ AHN Clero 1089/21 (1.III.1262).

${ }^{156}$ AHN Clero 1088/1 (8.IV.1258), publicado en Azevedo (1986), doc. 21, pp. 70-1.

${ }^{157}$ AHN Clero 1088/7 (17.IX.1258), 11 (15.II.1259).

${ }^{158}$ Sabemos poco de la organización de los arciprestazgos de la zona. Entre los arciprestes citados en el distrito están: Stephanus Nuniz, AHN Clero 1328A/18 (20.VII.1241); probablemente fue el mismoStephanus Nuniz presbyter que aparece entre los testigos de un documento de Vilameá, 1329B/19 (2.IX.1257), y, citado como quondam prelati ecclesie de Sancto Vincentio de Muris (Burgo), como el padre de Rudericus Muniz presbyter, 1329F/9 (1.IV.1260); Iohannes Iohannis clericus de Asperant, 1330F/3 (10.IX.1267), archipresbyter de Asperante, 1330F/8 (30.I.1268).

"CUADERNOS DE ESTUDIOS GALLEGOS", Tomo XLIII, Fascículo 108, Sántiago 1996. 
caritativas incluyeron cinco sueldos para los enfermos de Lugo, veinte para la obra de la catedral, veinte para el albergue, y las mandas simbólicas de un sueldo cada una a las catedrales de Santiago y Oviedo, el santuario de Sta. Mariña de Augas Santas, y el puente de Ourense, testimonios de una devoción religiosa que sobrepasó los horizontes locales.

Fernandus Nuniz nunca fue titulado presbyter y no hay ningún testimonio explícito de que fuera el prelado de la iglesia de San Cibrao. De todas formas, pocos clérigos relacionados con las parroquias vecinas llevaron el título de presbyter. Entre ellos, solo encontramos a Pelagius Sancti Martini presbyter, citado en 1241 probablemente en relación con San Martiño de Monte de Meda o Vilameá, y Iohannes Suariz, quizás relacionado con Entrambasaugas, donde compró propiedades, atestiguando transacciones en las parroquias vecinas de Sirvián y Vilameá. ${ }^{159}$ En cambio, hay varios ejemplos de clerici. Iohannes Vermudiz, el clérigo de San Martiño, bien de Vilameá o de Monte de Meda, fue uno de los beneficiarios del testamento de Fernandus Nuniz. Petrus Petriclericus de Lamela atestiguó un documento de Vilameá en 1244, y Petrus Iohannis clericus fue vinculado con Trastulfe en $1251 .{ }^{160}$ Pelagius Petri fue titulado clericus de Calde en 1260, y Baçarius y Dominicus Cipriani aparecen así titulados en un documento de $1271 .^{161}$

En principio, la conexión expresa de los clérigos con un lugar determinado no indica más que su lugar de origen o de residencia sin implicar necesariamente su ejercicio de la cura de almas. En estas escuetas noticias, el orden de las palabras tampoco significa una distinción, la cual no preocupaba demasiado a los escribas. El prelado de Sta. María de Mougan, por ejemplo, fue titulado Fernandus Iohannis clericus de Mougan y Fernandus Iohannis de Mougan clericus, como el presunto párroco de Sta. Cruz de Retorta, Petrus Fernandi, titulado clericus de Sancta Cruce y de Sancta Cruce presbyter. ${ }^{162}$ Aunque estos pueden ser

159 AHN Clero 1085/11 (IX.1241); Iohannes Suariz presbyter: 1328A/18 (20.VII.1241), 1327H/6 (I.1242), 1329B/19 (2.IX.1257).

${ }^{160}$ AHN Clero 1085/16 (2.I.1244); 1086/14 (17.IV.1251). Petrus Iohannis clericus fue uno de los testigos de un documento de Pradeda, 1086/4 (31.I.1248).

${ }^{161}$ AHN Clero 1329H/13 (1260); 1330G/15 (11.I.1271).

162 Mougan: AHN Clero 1086/20 (2.I.1254), 1329A/8 (25.VIII.1255); Retorta: 1328A/18 (20.VII.1241), 1329D/2 (7.IX.1258).

"CUADERNOS DE ESTUDIOS GALLEGOS", Tomo XLIII, Fascículo 108, Santiago 1996. 
ejemplos de párrocos que ejercían en sus propios lugares de origen, parecidas variaciones en la titulación de caballeros y artesanos aconsejan precaución a la hora de interpretar su significado.

La rareza de referencias explícitas a los sacerdotes en este distrito puede ser atribuida, en parte, a la naturaleza de una documentación escasa o a las costumbres de los escribas, pero también insinúa que algunos de estos clérigos actuaron como párrocos, una afirmación apoyada, en parte, por la aplicación del título de prelado a varios clérigos que nunca llevaron el título de sacerdote. ${ }^{163}$ Es posible que los notarios decidieran limitar el uso del título de sacerdote cuando éste se viera comprometido por la ruptura del celibato. ${ }^{164}$ Este podría haber sido el caso del mencionado Fernandus Nuniz, cuyo capellán, Martin Iohanis, atestiguó su testamento y recibió una de las mandas. Cabe preguntarse si Fernandus Nuniz gozó de los privilegios del párroco, pero delegó la cura de almas a un capellán que tenía órdenes sacerdotales, muy probablemente el antecesor de los clérigos mercenarios. Pese al creciente protagonismo del clero local en la documentación, las escuetas referencias no nos permiten más que estas reflexiones sobre el ejercicio de las funciones parroquiales, a la espera de estudios comparativos de las zonas vecinas.

Algunos documentos ofrecen datos sobre la condición social o relaciones familiares de los clérigos. Fernando Nuniz de San Cibrao fue titulado dom en el último documento en que apareció, y Odarius de Constante clericus llevó el título domnus en su única citación. ${ }^{165}$ Ioan Travesso, clérigo de Santiago de Peraredo, y P. Travesso, maiordomo do bispo, que aparecen citados en el mismo documento son probablemente hermanos. ${ }^{166}$ Ya identificamos a P. Travesso con Petrus Ruderici, quien sucedió a Rudericus Bazarius, probablemente su padre. De la misma familia podría ser Baçarius, el clérigo de Calde citado en un documento de

\footnotetext{
${ }^{163}$ Este fue el caso de I. Fernandi en Ligonde, Fernandus Iohannis en Mougan, Martinus Petri en Ourol, Petrus Pelagii en Orbazai y P. Crimentii en Santa Euxea.

${ }^{164}$ Sobre los frustrados intentos de imponer el celibato al clero español en el siglo XIII: P. Linehan, The Spanish Church and the Papacy in the Thirteenth Century, Cambridge 1971, 2-4, 29-30, 50-52, 66-67, 83-84.

165 D. Fernandus Nuniz: AHN Clero 1088/11 (12.II.1259); D. Odarius: 1086/1 (29.I.1247).

${ }^{166}$ AHN Clero 1091/17 (7.V.1272).
}

"CUADERNOS DE ESTUDIOS GALLEGOS", Tomo XLIII, Fascículo 108, Santiago 1996. 
1271. Dado el derecho de los propietarios a presentar a los clérigos, hay que suponer o que la familia Bazarius retuvo derechos en estas iglesias o que el obispo nombró miembros de la familia que le sirviera durante tanto tiempo. La relación entre clérigo y merino no fue sorprendente en absoluto, ya que en otros distritos del coto hubo clérigos que actuaron como merinos, como Martinus Iohannis en Coeses entre 1257 y 1258 o Petrus Pelagii en Orbazai en 1267. ${ }^{167}$

\section{LA DIVERSIDAD DE LAS IGLESIAS DEL DISTRITO Y SU INTEGRACIÓN EN LA RED PARROQUIAL}

Las fuentes no nos permiten ser más precisos sobre el clero parroquial o los propietarios de iglesias, pero sí ofrecen una visión de conjunto de la red parroquial en los siglos XII y XIII. Si ésta se corresponde en gran medida con la actual, también es cierto que la condición de estas iglesias en el siglo XIII todavía guarda las huellas de sus diversos orígenes e historia. De las catorce parroquias que conforman el distrito en la actualidad, la única iglesia de la que carecemos de información sobre sus propietarios es la de Lamela. Este silencio documental podría ser significativo, ya que la villa de Lamela fue el único lugar del distrito nombrado en el testamento de Odoarius y la iglesia fue incluída en el privilegio atribuído a Alfonso III. La falta de compraventas o donaciones de la iglesia en los siglos XII y XIII podría indicar su posesión íntegra por la sede, lo que confirmaría, al menos en este caso concreto, el contenido de los privilegios antiguos. ${ }^{168}$

El monasterio de Ferreira de Pallares poseyó porciones importantes de las iglesias de Entrambasaugas y Pradeda, también citadas en el privilegio de Alfonso III. Si, a primera vista, ésto desmentiría el controvertido diploma, merece notarse que Ferreira poseyó la mitad de la iglesia de

${ }^{167}$ Martinus Iohannis: AHN Clero 1329B/19 (2.IX.1257), 21 (6.II.1257), 1329D/7 (15.X.1258); Petrus Pelagii: 1328H/20 (9.II.1255), 1329G/14 (20.VII.1260), 1330F/4 (11.IX.1267).

${ }^{168}$ En 1755 , el patronato de la iglesia perteneció al rey y al obispo, García Conde y López Valcárcel (1991), 766.

"CUADERNOS DE ESTUDIOS GALLEGOS", Tomo XLIII, Fascículo 108, Santiago 1996. 
Entrambasaugas y la mayor parte — casi tres cuartas partes- de la de Pradeda. La relativa integridad de estas partes es excepcional. En el caso de Pradeda, la integridad de una mitad de la iglesia se remonta a su posesión por Rudericus Ruderici a principios del siglo XIII. ${ }^{169}$ De él no sabemos más, pero la iglesia de Entrambasaugas perteneció a la familia de los fundadores de Ferreira de Pallares, al igual que la iglesia de Sirvián. Las circunstancias de la fundación de estas iglesias y de su adquisición por la familia condal permanecen en la oscuridad, pero su relativa integridad en los siglos XII y XIII así como su citación en los privilegios altomedievales las distinguen de las iglesias cercanas.

La citación de estas iglesias en el privilegio de Alfonso III, la gran extensión de sus parroquias actuales, y su relativa integridad frente a la intensa repartición de las parroquias vecinas sugieren tanto la antigüedad de su fundación y la delimitación de sus parroquias como la intervención de las autoridades eclesiásticas o los propietarios más poderosos en su establecimiento. Esta hipótesis se apoya también en una comparación de estas tres iglesias con la parroquia actual de Vilameá y las iglesias desaparecidas de Trastulfe y Pradedo, todas enclavadas en el centro del triángulo formado por las parroquias de Entrambasaugas, Pradeda y Lamela. El mismo nombre de Vilameá, derivado de villa mediana, implica su separación de otra villa colindante, quizás la de Lamela. La cronología relativa de las villas no determina la de sus iglesias, pero se conforma al menos con la relación jerárquica sugerida por los datos sobre los propietarios de la iglesia y la menor extensión de la parroquia. De los modestos precios de treinta y veinte sueldos, se deduce que las ventas de quiñones en la iglesia en 1257 y 1262 se trataron de porciones pequeñas, fruto de reparticiones entre pequeños propietarios. ${ }^{170}$ Las 515 hectáreas que componen la parroquia actual de Vilameá representaron en el siglo XIII la extensión total de las tres pequeñas parroquias, aumentando así la diferencia entre éstas y las parroquias de Entrambasaugas, Lamela y Pradeda.

${ }^{169}$ En mi opinion, no se puede identificar este propietario, citado como Rudericus Ruderici de Pradeda, con el Rudericus Ruderici miles que sirvió al obispo en la vecina parroquia de Campo, cit. n. 55

${ }^{170}$ AHN Clero 1329B/19 (2.IX.1257), 1089/21 (1.III.1262).

"CUADERNOS DE ESTUDIOS GALLEGOS", Tomo XLIII, Fascículo 108, Santiago 1996. 
La desaparción de las iglesias de Trastulfe y Pradedo también refleja su condición subalterna. Antes de la supresión de Santiago de Pradedo en el arreglo parroquial de 1890, su pequeña extensión le proporcionaba una existencia precaria, y el mismo nombre anticipó su desparición, con la asimilación del nombre antiguo, Peraredo, al de su vecina más importante, Pradeda. ${ }^{171}$ La iglesia fue citada sin advocación en la bula papal de 1185, y el lugar fue mencionado sin ninguna referencia a la iglesia en la compilación de posesiones del monasterio de Ferreira. Carecemos de otras referencias a la iglesia anteriores a 1272 cuando la venta de una heredad de la parroquia a cinco grupos familiares nos revela la fragmentación de bienes entre pequeños propietarios. ${ }^{172}$ En el caso de Trastulfe, una capilla de San Estebo marcó, hasta tiempos recientes, lo que debe haber sido el emplazamiento de la antigua iglesia. En 1221 el obispo la cedió a $\mathrm{D}^{\mathrm{a}}$. Eldoncia Martini por su vida en un contrato que, según parece, comprendió los derechos parroquiales de la iglesia:

...do atque concedo in prestimonium ecclesiam sancti Stephani de Transtulfi ad Lucensem ecclesiam iure spectante hereditario cum caractere parrochie iamdicte ecclesie... ${ }^{173}$

En un momento en el que las concesiones de iglesias a laicos ya eran infrecuentes, ésta podría marcar el primer paso en la eliminación de Trastulfe de la red parroquial. ${ }^{174}$

La investigación de estas seis parroquias colindantes sugiere que las iglesias de Vilameá, Trastulfe y Pradedo fueron fundadas en los márgenes de las parroquias mayores de Lamela, Entrambasaugas y Pradeda,

171 García Conde y López Valcárcel (1991), 579-81, 794-96; A. Moralejo Laso analizó la derivación de los topónimos Pradeda, Pradedo y otras variantes, y la forma Peraredo no figura en su discusión de los antecedentes de Pradedo: «Topónimos variables con nasal o sin ella: en -edo/a o -endo/a,» Toponímia gallega y leonesa, Santiago 1977, 346-48. Esto me sugiere la posibilidad de una asimilación al topónimo de la parroquia vecina.

${ }^{172}$ AHN Clero 1091/17 (7.V.1272).

${ }^{173}$ AHN Clero 1327A/26, 27 (27.III.1221).

${ }^{174}$ Hay indicaciones de que la parroquia pervivió hasta tiempos modernos. Entre los papeles de San Miguel de Constante, una lista de rentas de varias parroquias de la zona, fechada en 1600, incluye San Estevo de Trasulfee: AHN Clero, leg. 3262.

"CUADERNOS DE ESTUDIOS GALLEGOS", Tomo XLIII, Fascículo 108, Santiago 1996. 
separándose de éstas a lo largo de los siglos. Tanto los antiguos privilegios de Lugo como los datos acerca de su posesión en los siglos XII y XIII insinúan que éstas fueron establecidas con una amplia jurisdicción por iniciativa del obispo o de los grandes propietarios en las correspondientes villas. Por su parte, las iglesias de Vilameá, Trastulfe y Pradedo rigieron territorios más reducidos, quizás como resultado de su fundación como capillas subalternas o iglesias propias de haciendas menores, y en dos casos, esta condición contribuyó a su desaparición final.

La desaparición de las iglesias de Trastulfe y Pradedo también subraya la importancia de las villas, como núcleos principales de asentamiento, en la formación de la red parroquial. ${ }^{175}$ Los documentos no las relacionan con villa alguna, y en el caso de la pequeña parroquia de Vilameá, su propio nombre indica, como ya comentamos, el fraccionamiento de una villa colindante. Las parroquias de Pradeda y Lamela correspondieron a las villas del mismo nombre, y el amplio territorio de Entrambasaugas, comprendió varias villas, según el privilegio atribuido a Alfonso III, una noticia apoyada por la existencia de numerosos poblados en la parroquia actual. La conformidad de las parroquias con las villas resulta muy sugerente. Estas parroquias podrían ser los vestigios de una red de iglesias propias fundadas por los grandes propietarios de las villas, una red que podría haberse mantenido a pesar de la transformación de las villas en las aldeas que sustituyeran a las grandes explotaciones agrarias durante la alta edad media.

De hecho, existe una relación consistente entre las parroquias y las villas del distrito. La donación del realengo de Monte Auto en 1161 nombró una serie de villas que se corresponden con las parroquias actuales de Sirvián, Lamela, Gomelle, San Cibrao de Monte de Meda y Vilameá. ${ }^{176}$ De éstas, las dos villas de las parroquias más pequeñas en la actualidad tomaron su nombre de la advocación de sus iglesias, Villa Sancti Cristofori y Villa Sancti Cipriani. Esto podría indicar el

${ }^{175}$ Sobre la evolución de las villas como núcleos de asentamiento: M.C. Pallares Méndez y E. Portela Silva, «Aproximación al estudio de las explotaciones agrarias en Galicia durante los siglos IX al XII,» Actas de las I Jornadas de Metodologia Aplicada de las Ciencias Históricas, II, Historia Medieval, Santiago 1975, 99-108; Baliñas Pérez (1992), 194-230.

176 cit. n. 35.

"CUADERNOS DE ESTUDIOS GALLEGOS", Tomo XLIII, Fascículo 108, Santiago 1996. 
establecimiento relativamente tardío de estas pequeñas villas acompañando la fundación de las iglesias. La única villa citada en esta donación que no pervivió como parroquia es precisamente la de San Adrián de Montouto, hoy capilla en la parroquia de Sirvián. Tras la concesión real de la mitad de la iglesia y villa a Petrus Eriz en 1161, la iglesia de San Adrián de Montouto no vuelve a ser citada en la documentación anterior a 1270, pero su condición de parroquia se infiere de un documento del siglo XV. ${ }^{177}$ En 1186, el obispo D. Rodrigo II compró una heredad en el villar de Breteos que, situado a quinientos metros, es el poblado más próximo a Montouto. De hecho, el texto localiza Breteos iuxta Monte Outo sin mencionar la iglesia y Martinus Petri de Monte Outo fue uno de los testigos. ${ }^{178}$ Otro lugar próximo, Treilán, formó parte de la parroquia de Lamela, según un documento de $1238 .{ }^{179}$

La exclusión de Montouto de la red parroquial no es fácil de explicar, si tenemos en cuenta que el privilegio de 1161 enumera los importantes derechos de la villa de Montouto en las villas circundantes. Dado que el privilegio real fue copiado en el Tumbo Viejo, se supone que la iglesia —o al menos la mitad que perteneció a Petrus Eriz- habría pasado a la catedral, pero, como ya indicamos, la bula del papa Lucio III de 1185 se limitó a citar la villa, y no la iglesia, entre las posesiones de la catedral. Desconocemos las circunstancias de su transferencia al obispo, pero sabemos que, en la organización del nuevo coto, Montouto fue eclipsada por la parroquia vecina de Sirvián. La torre de Sirvián fue la base de la defensa del coto en este sector, y la importancia de Sirvián en la baja edad media quedó reflejada en el establecimiento de la terraria de Sirvián, heredera de las nacientes merindades del siglo XIII. ${ }^{180}$ Relativamente aislada en el monte, la iglesia de San Adrián de Montouto no poseía un territorio poblado para constituir una parroquia. La alusión a sus derechos en las villas del distrito fue el legado de una época en la que la iglesia dependió de un patrimonio disperso incompatible con la consolidación de una red parroquial.

${ }^{177}$ AHN Cód. 417B, f. 38r (24.I.1478).

${ }^{178}$ AHN Clero 1325G/22 (3.III.1186).

${ }^{179}$ AHN Clero 1327H/18 (7.V.1238).

${ }^{180}$ AHN Cód. 417B, f. 2r (1482), 58v (17.I.1487). En 1251 Petrus Ruderici ya fue titulado mayordomo de terra et de torre de Serviam, anticipando la formación de la terraria, cit. n. 60 .

"CUADERNOS DE ESTUDIOS GALLEGOS", Tomo XLIII, Fascículo 108, Santiago 1996. 
San Miguel de Constante podría ser otra parroquia cuya jurisdicción antigua sobrepasó sus límites actuales, ejerciendo cierta autoridad sobre las parroquias vecinas. De esta jurisdicción hizo eco el privilegio real de 1167 ampliando el coto de Lugo. ${ }^{181}$ En éste, se identificó el territorio entre el coto viejo y el coto del monasterio de Ferreira con San Miguel de Constante, especificando unos límites que llegaron al coto de Retorta y se extendieron sobre la docena de iglesias citada en las cartas papales. De hecho, el territorio abarcó tanto las parroquias antiguas de Lamela y Entrambasaugas como las villas citadas en la donación de Montouto, y no es fácil desenredar los vestigios de estas antiguas jurisdicciones superpuestas. Constante fue también una villa y continuó como centro administrativo de un distrito más amplio, una terraria que, en la baja edad media, tomó su nombre de Fargós, el mismo lugar de la parroquia que fue cedido al merino, Rudericus Bazarius, quien actuó en gran parte de la zona colindante. ${ }^{182}$

La citación de una segunda iglesia, enclavada en la actual parroquia de San Miguel de Constante, es otra señal de la antigua importancia de Constante. San Xurxo de Constante fue relacionada frecuentemente con San Miguel de Constante en la localización de propiedades en diversos documentos. Que no se trata de una doble titularidad lo prueba la donación de Rudericus Bazarius quien separó la cesión de su voz eclesiástica en San Miguel de Constante de la de sus posesiones o derechos laicos en San Xurxo. ${ }^{183}$ En otros casos, tanto porciones de San Xurxo como porciones de San Miguel formaron parte de la donación de Joam Perez al monasterio de Ferreira y de una venta particular de $1273 .{ }^{184}$

Evidentemente San Miguel fue la más importante de las dos iglesias. Textos importantes, como el privilegio real de 1167 o la bula papal de 1185, citan únicamente a San Miguel. Tampoco apareció San Xurxo en el

\footnotetext{
181 cit. n. 36.

${ }^{182}$ Villa de Constante: AHN Clero 1326B/5 (12.XII.1197); terraria de Fargós: AHN Cód. 417B, f. 45r (2.XI.1479), 62r (7.II.1480). Tras una visita al monasterio de Ferreira, el obispo D. Michael expidió una carta apud Fargaos tratando de la distribución de las rentas del monasterio: 1084/8 (12.X.1231). Pelagius Pelagii fue titulado maiordomus de Fargaox: 1330F/14 (23.V.1268).

183 cit. n. 86

${ }^{184}$ cit. n. 112 y 138.
}

"CUADERNOS DE ESTUDIOS GALLEGOS", Tomo XLIII, Fascículo 108, Santiago 1996. 
citado cuaderno del monasterio de Ferreira que recogió noticias de numerosos bienes en Constante y parroquias vecinas. San Xurxo nunca aparece citada sin San Miguel, y es generalmente subordinada a ésta. La mayoría de las citaciones de San Xurxo prescinden del nombre del lugar, Constante, normalmente ligado a San Miguel. ${ }^{185}$ Por ejemplo una pequeña venta de 1253 da a entender que sus jurisdicciones coinciden, localizando una heredad in casali de costante...sub aula sancti michaelis de costante et sub aula sancti georgii. ${ }^{186}$ No obstante la única vez que el término filigrigia fue empleado, in tota filigrigia Sancti Michaelis de Costante et Sancti Georgii, el uso del singular implica que las dos iglesias formaron una sola parroquia. ${ }^{187} \mathrm{Al}$ parecer, el proceso que llevó a la desaparición de San Xurxo ya estaba avanzado en el siglo XIII, y la toponímia mayor del distrito no guarda el recuerdo del lugar. ${ }^{188}$

Otra pequeña parroquia limítrofe con Constante tuvo mejor suerte, pero la relevancia de San Miguel de Constante quedó también evidenciada en su relación con la parroquia de San Martiño de Monte de Meda, una de las pocas parroquias del distrito que no se corresponde con una villa. Sujeta a una fragmentación intensa, la iglesia fue relacionada con San Miguel de Constante en varias transacciones, y es posible que hubiera sido establecida como capilla con la expansión de los poblados de Constante hacía el monte. Esta hipótesis concordaría con la importancia dada a San Miguel de Constante en la ampliación del coto de 1167.

Si en su mayoría las parroquias se corresponden con las antiguas villas, en algunos casos también guardan las huellas de una fundación monástica. Este fue el caso de Castelo, mencionado entre los límites de San Miguel de Constante en la descripción de la ampliación del coto lucense en 1167. Esto implica una antigua acotación probablemente vinculada con el

185 AHN Clero 1326G/22 (18.XII.1215), 1327A/15 (13.IV.1220), 1086/1 (29.I.1247), 19 (21.XI.1253), 21 (22.VI.1254).

${ }^{186}$ AHN Clero 1086/19 (21.XI.1253).

${ }^{187}$ AHN Clero 1066/19 (1.XII.1241). En otros casos de la localización de heredades en dos parroquias se emplea la forma plural, 1328A/13 (8.XII.1240/Meilán y Bocamaos), 1328B/11 (13.IV.1243/Meilán y Bocamaos).

${ }^{188}$ El nombre del lugar de San Xurxo fue utilizado como apodo en el siglo XIII: Marina San Iurgo donó unos bienes en la vecina parroquia de Calde a la catedral para establecer un aniversario, AHN Cód. 1042B, f.6r, publicado por Jiménez Gómez (1987), 218

"CUADERNOS DE ESTUDIOS GALLEGOS", Tomo XLIII, Fașcículo 108, Santiago 1996. 
establecimiento de un monasterio. De hecho, en la documentación de los siglos XII y XIII, la iglesia de Castelo fue la única del distrito de nuestro estudio que recibió el título de monasterio, a pesar de que no hay evidencia de una comunidad monástica allí en estos siglos. ${ }^{189}$ En 1271, Rodrigo Ovequez prelado de moesterio de castello aparece entre los téstigos de un documento privado. ${ }^{190}$ Otros textos sugieren la lectura de monasterio como topónimo. En un documento de 1215, se localizan las heredades así: discurrente ad ecclesiam Sancte Eolalie de Plataneda... discurrente ad ecclesiam Sancti Saluatoris de Monasterio de Castello. ${ }^{191}$ Del paralelismo estricto entre Plataneda y Monasterio de Castello, se concluye que éste se refiere simplemente a un lugar. En el pleito de 1250 entre un monje de Ferreira y los hombres de Gracioes (Grazós), se cita la hereditatem de monasterio, y el escriba añadió las palabras de Castello entre líneas para evitar la confusión con el monasterio de Ferreira. ${ }^{192} \mathrm{La}$ omisión inicial se entiende mejor si Monasterio de Castelo hubiera sido un mero topónimo y el escriba hubiera reconocido la posible confusión con la abadía de Ferreira sólo en una revisión del texto.

No obstante, otros indicios confirman la fundación monástica de la parroquia en la alta edad media. La parroquia actual ocupa 840 hectáreas, una extensión sólo superada por las de Entrambasaugas, Ferreira de Pallares y Villamaior de Negral entre las parroquias del municipio actual de Guntín. Dos lugares de la parroquia - San Martiño y Sanxillaoprobablemente derivan sus nombres de antiguas capillas que habrían formado parte de una de las pequeñas congregaciones monásticas características de la Galicia altomedieval. ${ }^{193}$

En la mayoría de los casos mencionados, los cambios que habrían dado lugar a la red parroquial actual o ya habían ocurrido o estaban muy

${ }^{189}$ Fue titulado así en las donaciones de Marina Petri y Joam Perez, cit. n. 92 y 112.

${ }^{190}$ AHN Clero 1091/12 (10.V.1271).

${ }^{191}$ AHN Clero 1083/2 (29.V.1215).

${ }^{192}$ AHN Clero, 1086/12 (25.VII.1250).

${ }^{193}$ En la actualidad no hay capillas en estos lugares, pero se han hallado varios sarcófagos en el lugar de San Xillao: Valiña Sampedro, Inventario...de Lugo, II (1975), 80. Entre los papeles de S. Salvador de Castelo se guarda unApeo del lugar de San Julián de Mato del año 1691: AHN Clero, leg. 3261. El lugar fue también citado en los memoriales de rentas de Sta. Eulalia de Cuiña (AHN Clero, leg. 3262) y en el cuaderno de las posesiones del monasterio de Ferreira, cit. n. 126.

"CUADERNOS DE ESTUDIOS GALLEGOS", Tomo XLIII, Fascículo 108, Santiago 1996. 
avanzados en el siglo XIII. No obstante, por lo que se refiere a las advocaciones, varias iglesias recibieron sus advocaciones actuales después del siglo XIII. La actual iglesia de San Pedro de Calde aparece dedicada a San Salvador en documentos de 1208 y $1250 .{ }^{194}$ Sin embargo, las importantes donaciones de Rudericus Bazarius y $\mathrm{D}^{\mathrm{a}}$. Peironela la mencionan sin titular, omisión que a menudo representa un primer paso hacia el cambio de advocación, o hacia la desaparición de la iglesia. La iglesia de Gomelle, dedicada a San Cristobo y relacionada con la Villa Sancti Cristofori en la documentación medieval, hoy tiene a Santiago por titular. El cambio tiene fácil explicación: la fiesta de San Cristobo coincide con la de Santiago en el calendario romano. ${ }^{195}$ El cambio en el día de la fiesta del patrono dió lugar, con el paso del tiempo, al cambio en la advocación de la iglesia.

Otro caso interesante con relación al cambio del calendario litúrgico, es el de San Remixio de Bazar, una advocación compartida en Galicia solo con las iglesias de Liber (Becerreá) y Maceiras (Dozón). De esta dedicación no queda ninguna huella en la documentación de los siglos XII y XIII. Entre las parroquias citadas en un documento de 1273, se incluyó la de Sancti Vireximi de Bazar, lo que explica la referencia a San Verissimo en la descripción de los límites del coto lucense en el siglo XI; la localización de Paderni discurrente ad ecclesiam Sancti Vereximi en un documento de 1177; la designación de un testigo, Petrus Petri de Sancto Uerexemo, en una transacción en la parroquia vecina de Calde en 1208; y la localización de un casal in Brandian, sub aula de sancto vereximo. ${ }^{196}$

${ }^{194}$ AHN Clero 1326E/15 (1.VI.1208): la identificación con la iglesia actual de San Pedro de Calde se basa en la citación de Santa Eufemia, lugar de la actual parroquia, y la presencia de testigos de las parroquias cercanas de Soñar y Esperante; 1328E/2 (13.III.1250): esta transacción incluye heredades en la vecina parroquia de San Vicente de Muris (Burgo).

${ }^{195} \mathrm{P}$. David, «Le sanctoral hispanique et les patrons d'églises entre le Minho et le Mondego du IXe au XIe siècle,» Études historiques... (1947), 192-93. En el calendario mozárabe, la fecha de la fiesta era el 10 de julio: C. García Rodríguez, El culto de los santos en la España Romana y Visigoda, Madrid 1966, 207-08. Desconocemos la ocasión del cambio, pero el hallazgo de una losa sepulcral del siglo $\mathrm{X}$ en el lugar de Armental podría indicar un cambio en el emplazamiento de la iglesia que diera lugar al cambio de advocación con la dedicación de la iglesia actual.

${ }^{196}$ AHN Clero 1092/4 (25.XII.1273), 1334/5 (17.XII.1177), 1326E/15 (1.VI.1208), 1329A/22 (8.X.1256).

"CUADERNOS DE ESTUDIOS GALLEGOS", Tomo XLIII, Fascículo 108, Santiago 1996. 
Este lugar no existe en la actualidad, pero su ubicación en la parroquia de Bazar se establece por la citación del merino, Iohannes Lis, quien actuó en la vecina parroquia de Constante en 1253 y $1254 .{ }^{197}$ De hecho, la dedicación a San Breixo fue atestiguada a lo largo de la baja edad media. ${ }^{198}$ La celebración de la fiesta de San Breixo de Lisboa el 1 de octubre en el calendario mozárabe explica el cambio de la dedicación, ya que la misma fecha corresponde a la fiesta de San Remixio en el calendario romano. ${ }^{199}$

\section{CONCLUSIÓN}

La documentación de los siglos XII y XIII nos muestra una red parroquial en pleno proceso de consolidación, la cual, en gran medida, se corresponde a la actual. Esta documentación, aunque abundante en comparación con la acusada escasez de fuentes fiables de la alta edad media, también es parca en las noticias que nos proporciona. Unas listas de iglesias, las localizaciones de propiedades, las transferencias de porciones de iglesias, los nombres de propietarios y clérigos en datas o listas de testigos no constituyen precisamente las fuentes más eloquentes para el historiador, pero sí que hablan. Las diversas formas de repartición de las iglesias, la identidad de sus propietarios, la extensión de las parroquias, la toponímia, las relaciones de las parroquias con villas y monasterios, los cambios que sufrieron estas iglesias después del siglo XIII, son aspectos que nos ayudan a reconstruir la historia de estas parroquias.

\footnotetext{
${ }^{197}$ Los tres lugares de la provincia de Lugo que actualmente tienen esta denominación están en las parroquias de Vilauxe (Chantada), Robra (Outeiro de Rei) y Campo (Taboada); Iohannes Lis: AHN Clero 1086/19 (21.XI.1253), 1087/6 (15.XI.1254); el apodo se deriva del lugar de Liz en la vecina parroquia de Gomelle, y Iohannes Lis ya acompañó miembros de la casa episcopal entre los testigos de una donación de bienes en Sta. Marta (Fixós) y Muris (San Vicente do Burgo), 1328C/8 (2.II.1246).

${ }^{198}$ AHN Cód. 417B, f. 21v (4.IX.1388). Entre los papeles de los Cotos de Lugo, varios memoriales de rentas de la primera mitad del siglo XVIII citan a San Breixamo de Bazar, pero San Remixio fue el titular en la Razon...de piezas eclesiásticas...de Lugo del año 1755: AHN Clero, leg. 3262; García Conde y López Valcárcel (1991), 755.

${ }^{199}$ García Rodríguez (1966), 279-80.
}

"CUADERNOS DE ESTUDIOS GALLEGOS", Tomo XLIII, Fascículo 108, Santiago 1996. 
Reconozco que es muy aventurado avanzar hipótesis sobre los orígenes o «prehistoria» de un grupo reducido de iglesias y su configuración en una red parroquial, basadas en esta documentación, y aun más arriesgado pretender llegar a generalizaciones válidas para otras zonas gallegas. No obstante, la utilidad de la escueta información que las fuentes nos proporcionan depende de estudios locales que, poco a poco, reunan datos y ofrezcan hipótesis que, por aventuradas que sean, al menos proporcionen preguntas para plantear en un análisis más amplio. Tales estudios también permitirán un conocimiento de las costumbres de los distintos escribas, facilitando así el uso de la información contenida en pequeñas variantes de lenguaje y fórmulas diplomáticas, todo esto indispensable para sacar el máximo provecho de estas escuetas noticias. Siguiendo esta metodología se puede recuperar el valor de la forma y el contenido de la abundante documentación particular guardada en los pergaminos originales de los archivos de la catedral de Lugo y los monasterios de la diócesis.

Es evidente que las hipótesis avanzadas y los métodos aplicados en este artículo necesitan ser contrastados en zonas más amplias, pero esto dependerá de la existencia de estudios locales. Estos estudios pueden producir una visión de conjunto sobre la configuración de la red parroquial gallega, el contenido de la documentación altomedieval, y las conclusiones que se pueden sacar del análisis de la documentación de los siglos XII y XIII. Esta visión, a su vez, nos permitirá volver a estas localidades con nuevas hipótesis e instrumentos analíticos, estableciendo así una base más firme sobre la cual reconstruir la historia de la red parroquial y la historia de estas parroquias.

"CUADERNOS DE ESTUdiOS GALlEGOS", Tomo XLIII, Fascículo 108, Santiago 1996. 